\title{
Temporal and spatial fluctuations of sea surface temperature and chlorophyll $a$ levels due to atmospheric forcing in a tropical coastal lagoon
}

\section{Fluctuaciones espaciales y temporales de la temperatura superficial del mar y las concentraciones de clorofila $a$ debido a forzamientos atmosféricos en una laguna costera tropical}

\author{
José de Jesús Salas-Pérez*, Carlos González-Gándara \\ Facultad de Ciencias Biológicas y Agropecuarias, Universidad Veracruzana, km 7.5 Carretera Tuxpan-Tampico, \\ Tuxpan, Veracruz, CP 92860, México. \\ * Corresponding author. E-mail: jsalasp39@yahoo.es
}

\begin{abstract}
The temporal and spatial fluctuations of sea surface temperature (SST) and chlorophyll $a$ (Chla) levels due to atmospheric forcing in Mexico's third largest tropical coastal lagoon (Tamiahua Lagoon), located in the western Gulf of Mexico, was examined from July 2002 to May 2012. The main hypothesis of this study is that SST and Chla levels are modulated by the exchange of heat fluxes from the atmosphere and by rainfall (river runoff). The atmosphere supplies heat $\left(555.05 \pm 42.31 \mathrm{~W} \mathrm{~m}^{-2}\right)$ to Tamiahua Lagoon, which implies that the temperature of the lagoon over the period analyzed $\left(\sim 27^{\circ} \mathrm{C}\right)$ was higher than normal in the coastal zone. Precipitation regulates Chla levels during the rainy season because the cross-correlation values were high $(r>0.61)$ and the phase lag of the rainy season with the Chla time series was typically 0 to -1 month. El Niño/Southern Oscillation phases affected the rainfall patterns and, thus, Chla concentrations in the lagoon. As expected, the lagoon showed eutrophic conditions throughout the year (Chla concentrations $>5 \mathrm{mg} \mathrm{m}^{-3}$ ), with maximum values in the summer, when warm and wet conditions prevail. The annual scale is responsible for most of the variability in the two data sets. Seasonally, both oceanographic data sets showed three different water types, which, in both cases, were more variable at the southern and northern inlets and more homogenous in the central part of the lagoon.
\end{abstract}

Key words: Tamiahua Lagoon, precipitation, heat fluxes, annual scale, El Niño/Southern Oscillation.

RESUMEN. Las fluctuaciones espaciales y temporales de la temperatura superficial del mar (TSM) y las concentraciones de clorofila $a$ (Chla) debidas a forzamientos atmosféricos en la tercer laguna costera tropical más grande de México (laguna de Tamiahua), localizada en el oeste del golfo de México, fueron estudiadas de julio de 2000 a mayo de 2012. La principal hipótesis de este estudio es que la TSM y las concentraciones de Chla son moduladas por el intercambio de calor de la atmósfera y por la lluvia (descarga de ríos). La atmósfera introduce calor (555.05 \pm $\left.42.31 \mathrm{~W} \mathrm{~m}^{-2}\right)$ a la laguna de Tamiahua, lo cual implica que la temperatura de la laguna durante el periodo analizado $\left(\sim 27^{\circ} \mathrm{C}\right)$ fue mayor que la observada en la zona costera. La precipitación regula las concentraciones de Chla durante la temporada de lluvias porque los valores de las correlaciones cruzadas entre ambos parámetros fueron altos $(r>0.61)$ y la fase de retardo de la temporada de lluvias con las series de tiempo de la Chla generalmente fue de 0 a -1 mes. Las fases de El Niño/Oscilación del Sur afectaron los patrones de lluvia y, por lo tanto, las concentraciones de Chla en la laguna. La laguna muestra condiciones eutróficas a lo largo del año (concentraciones de Chla $>5 \mathrm{mg} \mathrm{m}^{-3}$ ), con valores máximos en verano, cuando las condiciones son cálidas y húmedas. La escala anual es responsable de la mayor variabilidad en ambos conjuntos de datos. Estacionalmente, ambos conjuntos de datos oceanográficos muestran tres diferentes tipos de agua, los cuales, para ambos conjuntos de datos, fueron más variables en las entradas de la zona sur y norte y fueron más homogéneas en la región central de la laguna.

Palabras clave: laguna de Tamiahua, precipitación, flujos de calor, escala anual, El Niño/Oscilación del Sur.

\section{INTRODUCTION}

Most of the coastal lagoons situated in the tropics and other regions of the world are shallow (Solidoro et al. 2004, Medina-Gómez and Herrera-Silveira 2006, Abreu et al. 2010), with depths no greater than $3 \mathrm{~m}$ in their main channels; therefore, the atmosphere, through heat fluxes and air temperature, has an important effect on water temperature patterns inside the lagoons. Lagoons are also affected by river discharges mainly during the rainy season. An example is the Venetian Lagoon (Italy), for which an analysis of the most

\section{INTRODUCCIÓN}

La mayoría de las lagunas costeras situadas en las zonas tropicales y en otras regiones del mundo son poco profundas (Solidoro et al. 2004, Medina-Gómez y Herrera-Silveira 2006, Abreu et al. 2010), con una profundidad de no más de $3 \mathrm{~m}$ en sus principales canales; por lo tanto, la atmósfera, a través de los flujos de calor y la temperatura del aire, tiene un efecto importante en la distribución espacial de temperatura del agua dentro de las lagunas. Por otra parte, las lagunas se ven afectadas por las descargas de los ríos, principalmente 
important water quality parameters confirmed the role of river discharges (which are enhanced during the rainy season) and exchanges promoted by tides with the sea in determining the water quality and the dynamics of the ecosystem (Solidoro et al. 2004). Unlike the Venetian Lagoon, Dzilam Lagoon (Yucatan Peninsula, Mexico) shows a decrease in primary production during the rainy season. The entry of large volumes of fresh water from direct precipitation and groundwater discharge into the lagoon is associated with short residence times of water during this season, causing reduced phytoplankton production despite the significant contribution of nutrients (Medina-Gómez and HerreraSilveira 2006).

Moreover, variations in chlorophyll a (Chla) levels appear to be most affected by hydrology, which is primarily driven by meteorological factors such as wind, rainfall, and evaporation. However, hydrological driving forces play different roles on different time scales. Thus, meteorological phenomena and variations in river runoff (Elliott and Quintino 2007) can promote interannual, annual, and seasonal fluctuations in sea surface temperature (SST) and Chla concentrations in lagoons. Nevertheless, for the Venetian Lagoon, the temperature fields are rather uniform, even if the effect of the exchanges with the sea can be recognized (Solidoro et al. 2004). Conversely, in the Patos Lagoon estuary in southern Brazil, rainfall and wind direction fluctuations have been observed to control temperature, salinity, water transparency, and Chla concentrations associated with shorter cycles in the spring than in the summer (Fujita and Odebrecht 2007). These effects have also been observed on the El Niño/Southern Oscillation (ENSO) time scale (Abreu et al. 2010).

\section{MATERIALS AND METHODS}

\section{Study area}

Tamiahua Lagoon is located in the coastal zone of Veracruz State, in the southwestern Gulf of Mexico (Fig. 1). The lagoon is $110 \mathrm{~km}$ long, $25 \mathrm{~km}$ wide, and has a depth of 1-3 m. It is important because of fishing, shellfish farming, and tourism. The lagoon is connected to the western continental shelf through two inlets (Fig. 1), where the exchange of water is promoted by the diurnal tide of the gulf basin (Salas-Pérez et al. 2008). Additionally, the lagoon receives discharges from many rivers (Fig. 1); however, discharge data do not exist. We assume that there is an increase in river input to the lagoon during the rainy season and hence fluctuations in SST and Chla concentrations related to precipitation and runoff. Moreover, the use of satellite imagery and meteorological data over a period of 10 years allowed us to study interannual signals such as El Niño and La Niña and evaluate whether these phenomena affect meteorological and thus oceanographic parameters within the lagoon. In Veracruz, El Niño/La Niña warm/cold conditions induce extreme rainfall durante la época de lluvias. Un ejemplo es la laguna de Venecia (Italia), para la cual un análisis de los parámetros de calidad del agua más importantes confirmó el papel de las descargas de los ríos (que son más importantes durante la época de lluvias) y de los intercambios de agua generados por las mareas con el mar en la determinación de la calidad del agua y la dinámica del ecosistema (Solidoro et al. 2004). A diferencia de la laguna de Venecia, la laguna de Dzilam (península de Yucatán, México) muestra una disminución en la productividad primaria durante la época de lluvias. La entrada de grandes volúmenes de agua fresca procedentes de la precipitación directa y la descarga de aguas subterráneas a la laguna se asocia con tiempos cortos de residencia de agua durante esta temporada, lo cual ocasiona una reducción en la producción de fitoplancton a pesar de la importante contribución de nutrientes (Medina-Gómez y Herrera-Silveira 2006).

Las variaciones en las concentraciones de clorofila $a$ (Chla) parecen ser más afectadas por la hidrología, que es afectada principalmente por factores meteorológicos como el viento, la lluvia y la evaporación. Sin embargo, se ha observado que las fuerzas que conducen las variaciones hidrológicas juegan diferentes papeles en diferentes escalas de tiempo. Por lo tanto, los fenómenos meteorológicos y las variaciones del caudal de los ríos (Elliott y Quintino 2007) pueden promover las fluctuaciones interanuales, anuales y estacionales en la temperatura superficial del mar (TSM) y en las concentraciones de Chla en las lagunas. No obstante, para la laguna de Venecia, los campos de temperatura son uniformes, incluso si los intercambios con el mar son importantes (Solidoro et al. 2004). Por el contrario, en el estuario Laguna de los Patos, en el sur de Brasil, se ha observado que la precipitación y las fluctuaciones de la dirección del viento controlan la temperatura, la salinidad, la transparencia del agua y la concentración de Chla asociada con ciclos más cortos en primavera que en verano (Fujita y Odebrecht 2007). Estos efectos también se han observado en la escala de tiempo de El Niño/Oscilación del Sur (ENOS) (Abreu et al. 2010).

\section{MATERIALES Y MÉTODOS}

\section{Área de estudio}

La laguna de Tamiahua está situada en la zona costera del estado de Veracruz, en el sudoeste del golfo de México (Fig. 1). La laguna mide $110 \mathrm{~km}$ de largo y $25 \mathrm{~km}$ de ancho, y tiene una profundidad de 1-3 m. Es importante por la pesca, el cultivo de moluscos y el turismo. La laguna está conectada a la plataforma continental occidental a través de dos entradas (Fig. 1), donde el intercambio de agua es generado por la marea diurna de la cuenca del golfo (Salas-Pérez et al. 2008). Además, la laguna recibe las descargas de muchos ríos (Fig. 1); sin embargo, no hay registros de estas descargas. Suponemos que hay un aumento de las descargas de los ríos a la laguna durante la época de lluvias y, por lo tanto, se incrementan las fluctuaciones de la TSM y las concentraciones de Chla relacionadas con la precipitación y la escorrentía. Por 

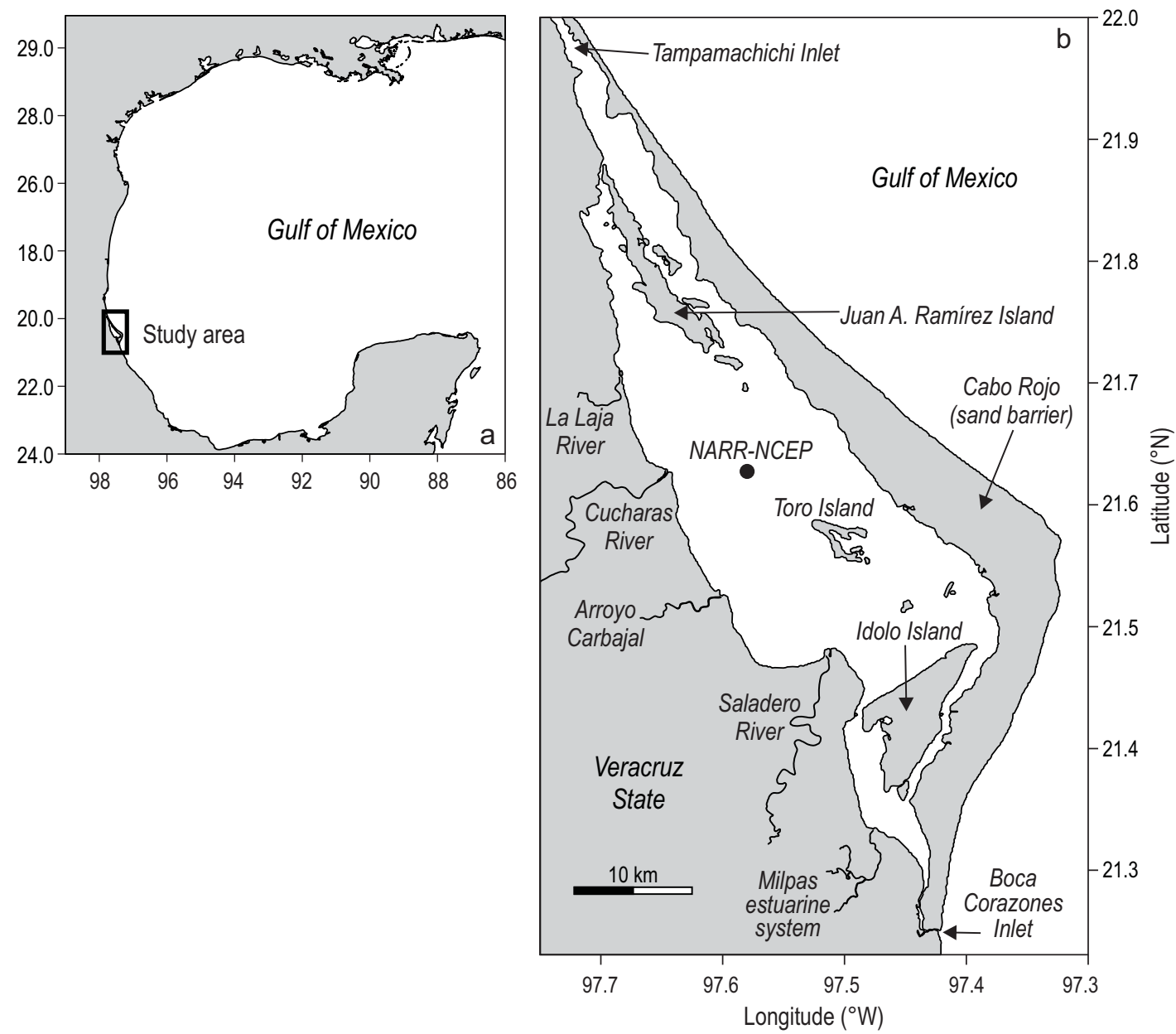

Figure 1. (a) Location of Tamiahua Lagoon in the southwestern Gulf of Mexico. (b) Inlets, islands, and rivers of Tamiahua Lagoon. The NARR/NCEP grid point in the center of the lagoon is indicated by a circle.

Figura 1. (a) Localización de la laguna de Tamiahua en el sudoeste del golfo de México. (b) Entradas, islas y ríos de la laguna de Tamiahua. El punto de la cuadrícula NARR/NCEP en el centro de la laguna se indica con un círculo.

episodes in winter/summer-fall and moderate episodes in summer/winter (Torres-Alavez et al. 2010). Coastal lagoons are under-represented in the literature. For Tamiahua Lagoon, there are no studies on SST and Chla spatial and temporal fluctuations at seasonal, annual, and interannual scales forced by rainfall and heat fluxes, which are necessary to better understand its hydrological features.

\section{Data set}

Monthly SST images from the NOAA-16 infrared channel and MODIS Level-3 monthly standard mapped images of Chla were used to elucidate SST and Chla temporal and spatial variability in Tamiahua Lagoon from July 2002 to May 2012, and thereby evaluate the hypothesis that fluctuations of these oceanographic parameters are mainly influenced by precipitation and heat fluxes. The SST images employed in this study were obtained from the Giovanni Ocean Color Radiometry Online Visualization and Analysis node, and the otra parte, el uso de imágenes de satélite y datos meteorológicos en un periodo de 10 años nos permitió estudiar señales interanuales como El Niño y La Niña y evaluar si estos fenómenos afectan a los parámetros meteorológicos y oceanográficos dentro de la laguna. En Veracruz, las condiciones cálidas/frías de El Niño/La Niña provocan episodios de lluvia extrema en invierno/verano-otoño y episodios moderados en verano/invierno (Torres-Alavez et al. 2010). Existe poca información sobre lagunas costeras en la literatura científica. Para la laguna de Tamiahua, no hay registros sobre las fluctuaciones espaciales y temporales de la TSM y Chla a escalas estacionales, anuales e interanuales forzadas por los flujos de calor y lluvia, que son necesarias para mejorar el conocimiento de sus características hidrológicas.

\section{Conjunto de datos}

Imágenes mensuales de la TSM del canal infrarrojo NOAA-16 e imágenes mensuales MODIS nivel-3 estándar de 
Chla images were obtained from the ERDAPP node. The spatial resolution is $0.0360^{\circ} \times 0.0360^{\circ}$ for the SST images and $0.0125^{\circ} \times 0.0125^{\circ}$ for the Chla images; in both cases, the resolution is good enough to characterize processes in Tamiahua Lagoon. Satellite images were used in this study instead of in situ measurements in the lagoon, which are not in the public domain and are also under-represented over the study period. The study area is well covered by satellite imagery (98\%). Therefore, this study was conducted using 119 monthly images of SST and Chla. The temporal fluctuations of SST and Chla were studied using time series built from the monthly satellite images. The spatial fluctuations in the SST and Chla images were then obtained from the means and standard deviations over the analyzed period, and seasonal averages from July 2002 to May 2012 were computed to obtain the climatologic fields of those parameters in Tamiahua Lagoon and thus describe their main patterns.

In situ atmospheric measurements were not used because there are no meteorological stations in the area of the coastal lagoon. Instead, the effect of air temperature, heat fluxes, and precipitation (river discharge) on the Tamiahua Lagoon waters was analyzed using the NARR/NCEP (North American Regional Reanalysis/National Center for Atmospheric Prediction) data set output model at $1000 \mathrm{mb}$ (Mesinger et al. 2006). The analyzed data were built at a point located near the center of Tamiahua Lagoon $\left(97.5549^{\circ} \mathrm{N}\right.$ and $\left.21.5506^{\circ} \mathrm{W}\right)$ (Fig. 1). It is important to stress that the observations from the NARR/NCEP meteorological model outputs only represent a point in the middle of the lagoon, and we assumed that the heat fluxes, air temperature, and rainfall were uniform throughout the lagoon. The crosscorrelations and phase lags between the atmospheric variables (heat fluxes and precipitation), oceanographic parameters (SST and Chla) and normalized precipitation anomaly (SPA $=\frac{S P-\bar{S} \bar{P}}{\sigma S P}$, where SPA represents the seasonal precipitation anomaly, $S P$ are individual values of seasonal precipitation, $\overline{S P}$ is the average of the complete seasonal precipitation time series, and $\sigma S P$ is the standard deviation of the total seasonal precipitation time series), in conjunction with the Oceanic Niño Index (ONI) (Reynolds et al. 2008) were calculated as follows. The cross-correlation was computed with the Matlab crosscorr function. This function was used to analyze the effect of the atmospheric parameters on Chla and precipitation, the SST and Chla time series, and the SST and heat flux time series. The Tamiahua Lagoon heat fluxes $\left(\mathrm{W} \mathrm{m}^{-2}\right)$ were computed with the bulk heat formula:

$$
\text { Qnet }=\mathrm{SW}-\mathrm{LW}-\mathrm{LH}-\mathrm{SH}
$$

where Qnet is the net heat flux, SW the shortwave radiation, LW the longwave radiation, LH the latent heat flux, and SH the sensible heat flux.
Chla se utilizaron para estudiar la variabilidad temporal y espacial de la TSM y Chla en la laguna de Tamiahua de julio de 2002 a mayo de 2012, y evaluar así la hipótesis de que las fluctuaciones de estos parámetros oceanográficos son influidos principalmente por la precipitación y los flujos de calor de la atmósfera. Las imágenes de TSM utilizadas en este estudio se obtuvieron del nodo Giovanni Ocean Color Radiometry Online Visualization and Analysis que está disponible en internet, y las imágenes de Chla fueron obtenidas desde el nodo ERDAPP. La resolución espacial de las imágenes de TSM es de $0.0360^{\circ} \times 0.0360^{\circ}$ y la resolución espacial de las imágenes de Chla es de $0.0125^{\circ} \times 0.0125^{\circ}$; en ambos casos, la resolución es suficiente para caracterizar los procesos oceanográficos en la laguna de Tamiahua. Las imágenes de satélite se utilizaron en este estudio en lugar de datos de mediciones in situ en la laguna, que no son de dominio público y están poco representados en el periodo de estudio. El área de estudio está bien cubierta por las imágenes de satélite (98\%). Por lo tanto, este estudio se realizó utilizando 119 imágenes mensuales de la TSM y Chla. Las fluctuaciones temporales de la TSM y Chla fueron estudiadas a través de series de tiempo construidas a partir de las imágenes de satélite mensuales. Las fluctuaciones espaciales de las imágenes de TSM y Chla fueron obtenidas a partir de los promedios y las desviaciones estándar durante el periodo analizado, y los promedios estacionales de julio de 2002 a mayo de 2012 fueron calculados para obtener los campos climatológicos de esos parámetros en la laguna de Tamiahua y, por lo tanto, describir sus características espaciales y temporales principales.

No se utilizaron mediciones atmosféricas in situ porque no hay estaciones meteorológicas en la laguna costera. En cambio, se analizó el efecto de la temperatura del aire, los flujos de calor y la precipitación (descarga de los ríos) en las aguas de la laguna de Tamiahua utilizando datos generados a $1000 \mathrm{mb}$ por el modelo NARR/NCEP (Reanálisis Regional Norteamericano/Centros Nacionales de Predicción Ambiental) (Mesinger et al. 2006). Los datos analizados fueron construidos en un punto situado cerca del centro de la laguna de Tamiahua $\left(97.5549^{\circ} \mathrm{N}\right.$ y $\left.21.5506^{\circ} \mathrm{W}\right)$ (Fig. 1). Es importante destacar que las observaciones del modelo meteorológico NARR/NCEP representan sólo un punto en el centro de la laguna de Tamiahua, y suponemos que los flujos de aire de temperatura, las precipitaciones y el calor son uniformes en toda la laguna. Las correlaciones cruzadas y el retardo de fase entre las variables atmosféricas (flujos de calor y precipitación), parámetros oceanográficos (TSM y Chla) y anomalías de precipitación normalizadas (APE $=\frac{P E-\overline{P E}}{\sigma P E}$, donde APE representa la anomalía de precipitación estacional, $P E$ es el valor individual de la precipitación estacional, $\overline{P E}$ es el promedio de la serie de tiempo completa de precipitación estacional, $\sigma P E$ es la desviación estándar de la serie de tiempo total de la precipitación estacional), en conjunto con 


\section{RESULTS}

\section{Temporal fluctuations of SST, air temperature, precipitation, and Chla concentrations}

Seasonal averages of the SST and air temperature time series built from monthly images and NARR/NCEP outputs over the period analyzed in this study showed well-defined annual signals (Fig. 2a). The mean difference between SST and air temperature in Tamiahua Lagoon was approximately $2{ }^{\circ} \mathrm{C}$. Thus, the differences in temperature between both curves were positive due to the heat transferred from the atmosphere to the lagoon throughout the year. Over the 10 years analyzed in this study, the mean SST and air temperature showed marked interannual fluctuations in the cold seasons (differences of approximately $1-3{ }^{\circ} \mathrm{C}$ ) and in the warm seasons, which presented nearly the same temperature differences (approximately $2-3{ }^{\circ} \mathrm{C}$ ) as observed in the cold seasons (Fig. 2a).

The seasonal precipitation time series revealed a clear annual signal during the analyzed period (Fig. 2b). The average precipitation was $3.0 \pm 2.90 \mathrm{~mm} \mathrm{month}^{-1}$. The minimum and maximum values in the period analyzed were $\sim 0.002 \mathrm{~mm} \mathrm{month}^{-1}$ (spring of 2011) and $\sim 23 \mathrm{~mm}$ month $^{-1}$ (summer of 2010), respectively. Seasonal precipitation time series displayed maximum values $\left(\sim 5\right.$ to $23 \mathrm{~mm}$ month $\left.^{-1}\right)$ in summer and minimum values (approximately 0.008 to $\left.0.43 \mathrm{~mm} \mathrm{month}^{-1}\right)$ in winter.

A clear Chla annual signal was observed (Fig. 2b) similarly to the other time series previously described, with maximum peaks between 13 and $40 \mathrm{mg} \mathrm{m}^{-3}$ throughout the summer and fall, in contrast to winter, during which minimum values of approximately 6 to $14 \mathrm{mg} \mathrm{m}^{-3}$ were observed. Spring showed minimum and maximum concentrations of 6 and $22 \mathrm{mg} \mathrm{m}^{-3}$, respectively. However, in general, as precipitation increased, the Chla concentration also increased.

Warmer temperatures, higher rainfall, and increased Chla were generally common features during the summer and fall (Fig. 2b). The cross-correlations between the seasonal precipitation and seasonal Chla time series showed values greater than 0.40 in all seasons (Table 1). The negative phase lags between those time series (Table 1) showed that seasonal precipitation occurred first, followed by the seasonal increase in Chla concentration. In general, high cross-correlations (about 1) were observed in the summer and fall, which agree with the seasonal periods of maximum precipitation in the study area, suggesting the influence of maximum river discharge into Tamiahua Lagoon. However, the crosscorrelation values were also higher than 0.6 in winter and spring (Table 1). The cross-correlation analysis showed a $P<0.00001$, indicating significant values. In general, the SPA in the last 4 years was highly positive compared with that in the first 6 years, during which the SPA showed low positive normalized precipitation anomalies (Fig. 2b, c). This el Índice Oceánico de El Niño (ONI por sus siglas en inglés) (Reynolds et al. 2008) se calcularon como sigue. La correlación cruzada se calculó con la función crosscorr de Matlab. Esta función se utilizó para analizar el efecto de los parámetros atmosféricos en Chla y la precipitación, las series de tiempo de TSM y Chla, y las series de tiempo de TSM y de los flujos netos de calor. El flujo neto de calor $\left(\mathrm{W} \mathrm{m}^{-2}\right)$ de la laguna de Tamiahua se calculó con la siguiente fórmula:

$$
\text { Qnet }=\mathrm{OC}-\mathrm{OL}-\mathrm{CL}-\mathrm{CS}
$$

donde Qnet es el flujo neto de calor, OC es la radiación de onda corta, OL es la radiación de onda larga, CL es el flujo de calor latente y CS es el flujo de calor sensible.

\section{RESUltados}

\section{Fluctuaciones temporales de la TSM, temperatura del aire, precipitación y concentraciones de Chla}

Los promedios estacionales de las series de tiempo de la TSM y las series de tiempo de la temperatura del aire construidas a partir de imágenes mensuales y salidas del modelo NARR/NCEP durante el periodo analizado en este estudio mostraron señales anuales bien definidas (Fig. 2a). La diferencia promedio entre la TSM y la temperatura del aire atmosférica en la laguna de Tamiahua fue de aproximadamente $2{ }^{\circ} \mathrm{C}$. Por lo tanto, las diferencias de temperatura entre las dos curvas fueron positivas debido al calor transferido desde la atmósfera a la laguna durante todo el año. Durante los 10 años analizados en este estudio, el promedio de la TSM y el de la temperatura del aire muestran fluctuaciones interanuales en las estaciones frías (diferencias de aproximadamente $1-3{ }^{\circ} \mathrm{C}$ ) y en las estaciones cálidas, las cuales presentaron casi las mismas diferencias de temperatura (aproximadamente $2-3{ }^{\circ} \mathrm{C}$ ) que las observadas en las estaciones frías (Fig. 2a).

Las series de tiempo de precipitación estacional presentaron una señal anual definida durante el periodo analizado (Fig. 2b). La precipitación promedio fue de $3.0 \pm 2.90 \mathrm{~mm}$ mes $^{-1}$. Los valores mínimos y máximos en el periodo analizado fueron $\sim 0.002 \mathrm{~mm} \mathrm{mes}^{-1}$ (primavera de 2011) y $\sim 23 \mathrm{~mm} \mathrm{mes}^{-1}$ (verano de 2010), respectivamente. Estacionalmente, las series de tiempo de precipitación muestran valores máximos $\left(\sim 5-23 \mathrm{~mm}\right.$ mes $\left.^{-1}\right)$ en verano y mínimos $\left(\sim 0.008-0.43 \mathrm{~mm} \mathrm{mes}^{-1}\right)$ en invierno.

Se observó una señal anual de la Chla (Fig. 2b) de manera similar a la serie de tiempo de precipitación descrita previamente, con picos máximos de entre 13 y $40 \mathrm{mg} \mathrm{m}^{-3} \mathrm{en}$ todo el verano y el otoño, en contraste con el invierno durante el cual los valores mínimos fueron de aproximadamente $6 \mathrm{a} 14 \mathrm{mg} \mathrm{m}^{-3}$. Las concentraciones mínimas y máximas en primavera fueron de 6 y $22 \mathrm{mg} \mathrm{m}^{-3}$, respectivamente. Sin embargo, en general, cuando la precipitación aumentó, la concentración de Chla también aumentó. 

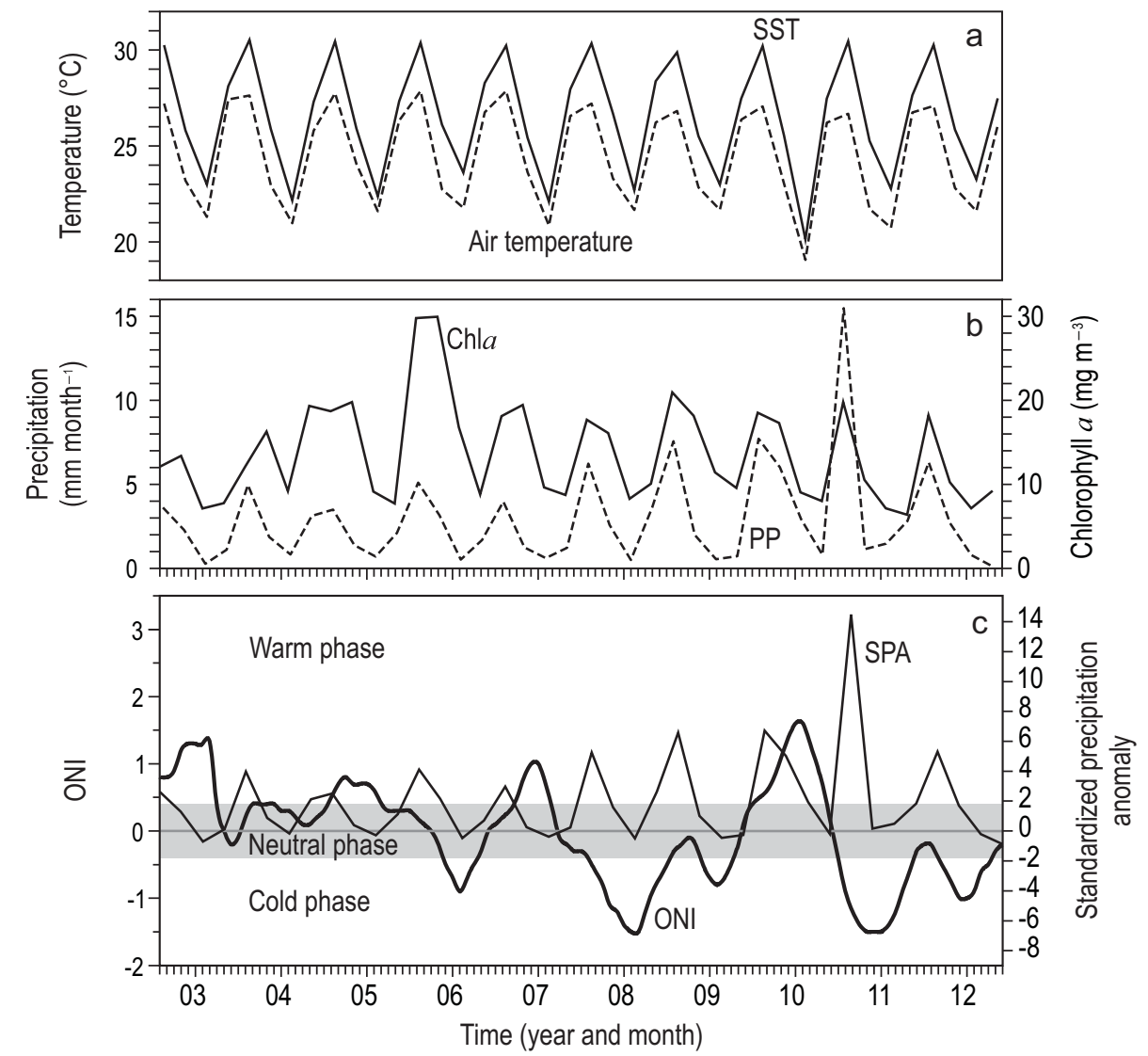

Figure 2. (a) Interannual time series of sea surface temperature (SST) and air temperature (dashed line). (b) Interannual precipitation (PP) and interannual time series of chlorophyll $a(\mathrm{Chla})$ computed by season. (c) Normalized precipitation anomaly (SPA) vs the Oceanic Niño Index $(\mathrm{ONI})$, in the ENSO warm and cold phases and in the neutral phase.

Figura 2. (a) Series de tiempo interanuales de la temperatura superficial del mar (SST) y la temperatura del aire atmosférico (línea discontinua). (b) Precipitación interanual (PP) y serie de tiempo interanual de la clorofila a (Chla) computarizada por temporada. (c) Anomalía de la precipitación normalizada (SPA) vs el Índice Oceánico de El Niño (ONI), en las fases cálida y fría de ENOS y en la fase neutral.

behavior may have been due to an interannual forcing mechanism, such as ENSO (warm and cold phases of the phenomenon), which qualitatively manifested its effect on the normalized precipitation anomaly time series of the study area (Fig. 2c). First, the SPA decreased when a warm phase (El Niño) occurred from July 2002 to February 2003 (9 months), from July 2004 to February 2005 (8 months), and from September 2006 to January 2007 (5 months). In contrast, a positive SPA occurred for the El Niño period in the resulting interval: from June 2009 to April 2010 (11 months). Meanwhile, during the La Niña phase, the SPA decreased from November 2005 to March 2006 (5 months), whereas from April to November 2007 (6 months) it was mainly positive, with a short period of negative SPA between December 2007 and February 2008. During the last period, February to November 2008 (10 months), and during the periods June 2009 to April 2011 (11 months), August to October 2010 (3 months), and April to November 2011, the SPA was also positive.
Las temperaturas más cálidas, las mayores precipitaciones y el aumento de Chla generalmente fueron características comunes durante el verano y el otoño (Fig. 2b). Las correlaciones cruzadas entre las series de tiempo de precipitación estacional y de la Chla estacional mostraron valores superiores a 0.40 en todas las estaciones (Tabla 1). Los retardos de fase negativos entre esas series de tiempo (Tabla 1) mostraron que la precipitación estacional se produjo primero, seguido por el aumento estacional de la concentración de Chla. En general, las altas correlaciones cruzadas (aproximadamente 1) se observaron en el verano y el otoño, que concuerdan con los periodos estacionales de precipitación máxima en el área de estudio, lo que sugiere la influencia del caudal máximo de las aguas de los ríos en la laguna de Tamiahua. Sin embargo, los valores de correlación cruzada también fueron superiores a 0.6 en las temporadas de invierno y primavera (Tabla 1). El análisis de correlación cruzada mostró una $P<0.00001$, lo que indica valores significativos. En general, la APE en los últimos 4 años fue altamente 
Table 1. Seasonal cross-correlation and phase lag between the rainfall and chlorophyll-a level time series (time series 1 and 2, respectively) from July 2002 to May 2012 at Tamiahua Lagoon. The significance levels of the computations were $P<0.00001$.

Tabla 1. Correlación cruzada estacional y fase de retardo entre las series de tiempo de la lluvia (serie de tiempo 1) y la concentración de Chla (serie de tiempo 2), de julio de 2002 a mayo de 2012 en la laguna de Tamiahua. Los niveles de significancia de los valores fueron de $P<0.00001$.

\begin{tabular}{lcllllllllll}
\hline Season & 2002 & 2003 & 2004 & 2005 & 2006 & 2007 & 2008 & 2009 & 2010 & 2011 & 2012 \\
\hline Winter & - & $0.62 / 0$ & $0.59 / 0$ & $0.61 / 0$ & $0.82 / 0$ & $0.73 / 1$ & $0.80 / 1$ & $0.82 / 0$ & $0.71 / 1$ & $0.97 / 0$ & $0.45 /-2$ \\
Spring & - & $0.65 /-1$ & $0.65 / 0$ & $0.48 /-1$ & $0.86 /-1$ & $0.43 / 0$ & $0.56 / 0$ & $0.92 / 0$ & $0.98 / 0$ & $0.34 /-2$ & $0.50 /-1$ \\
Summer & $0.81 / 0$ & $0.99 / 0$ & $0.68 /-1$ & $0.62 / 0$ & $0.60 / 1$ & $0.95 /-1$ & $0.99 / 0$ & $0.99 / 0$ & $0.40 / 1$ & $0.60 /-2$ & - \\
Fall & $0.91 / 0$ & $0.51 / 0$ & $0.67 /-1$ & $0.66 /-1$ & $0.70 /-1$ & $0.89 / 0$ & $0.98 / 0$ & $0.92 / 0$ & $0.46 /-1$ & $0.84 / 0$ & - \\
\hline
\end{tabular}
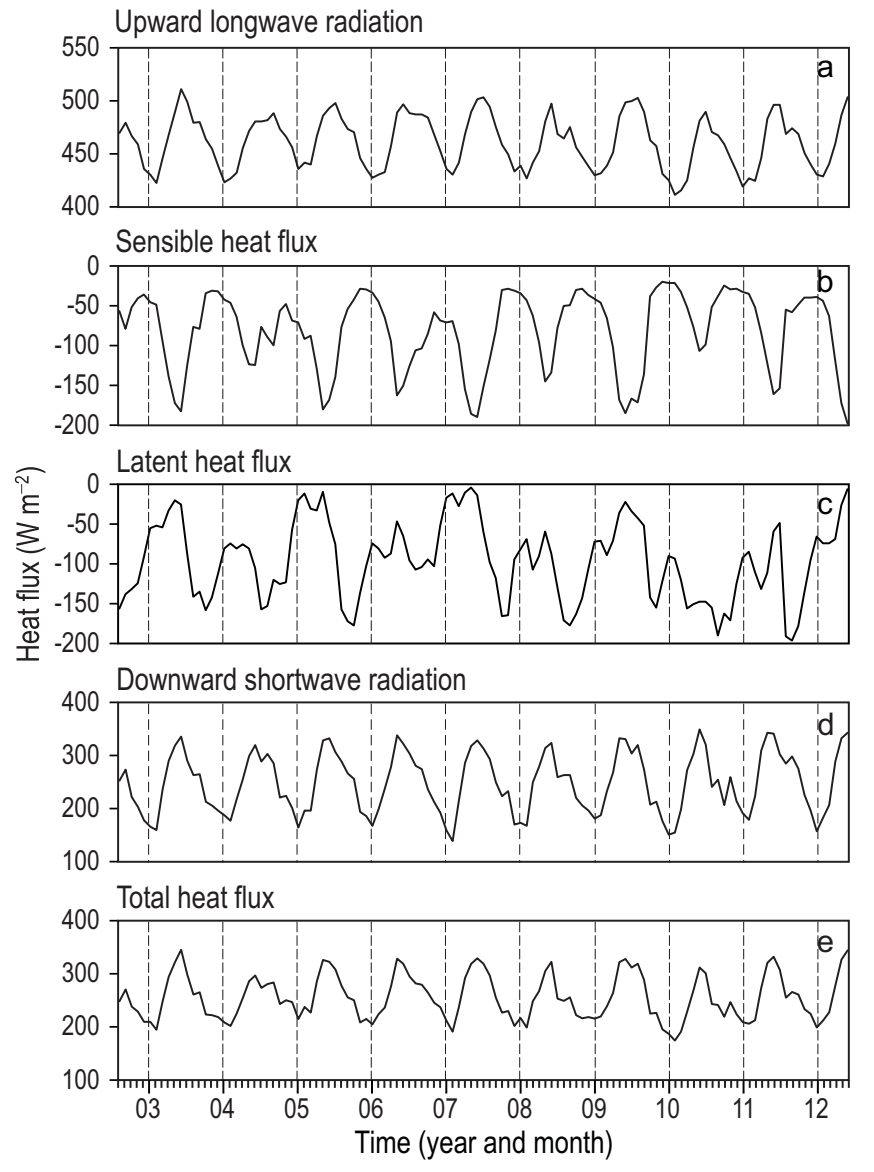

Figure 3. Temporal fluctuations of the time series of heat fluxes, from July 2002 to May 2012: (a) longwave radiation flux, (b) sensible heat flux, (c) latent heat flux, (d) shortwave radiation flux, and (e) net heat flux. Heat fluxes $>0$ indicate heat gain to the lagoon and $<0$ indicate heat loss to the atmosphere.

Figura 3. Fluctuaciones temporales de las series de tiempo de los flujos de calor, de julio de 2002 a mayo de 2012: (a) flujo de radiación de onda larga, (b) flujo de calor sensible, (c) flujo de calor latente, (d) flujo de radiación de onda corta, (e) flujo neto de calor. Los flujos de calor $>0$ significan una ganancia de calor neta hacia la laguna y $<0$ significan pérdidas de calor hacia la atmósfera. positiva en comparación con la de los primeros 6 años durante los cuales el APE mostró bajas anomalías de precipitación normalizadas positivas (Fig. $2 b, c)$. Este comportamiento puede deberse a un mecanismo de forzamiento interanual, tal como el ENOS (fases cálidas y frías del fenómeno), que cualitativamente manifestó su efecto en la anomalía normalizada de la serie de tiempo de lluvias de la zona de estudio (Fig. 2c). En primer lugar, la APE disminuyó cuando una fase cálida (El Niño) se produjo entre julio de 2002 y febrero de 2003 (9 meses), entre julio de 2004 y febrero de 2005 ( 8 meses) y entre septiembre de 2006 y enero de 2007 (5 meses). Por el contrario, una APE positiva se produjo durante el periodo de El Niño en el intervalo resultante: de junio de 2009 a abril de 2010 (11 meses). Durante el episodio de La Niña, la APE disminuyó entre noviembre de 2005 y marzo de 2006 (5 meses), mientras que entre abril y noviembre de 2007 (6 meses) fue principalmente positiva, y hubo un corto periodo de APE negativa entre diciembre de 2007 y febrero de 2008. Durante el último periodo, de febrero a noviembre de 2008 (10 meses), y los periodos de junio de 2009 a abril de 2011 (11 meses), de agosto de 2010 a octubre de 2010 (3 meses), y de abril a noviembre de 2011, la APE también fue positiva.

\section{Flujos de calor del modelo NARR/NCEP}

En general, casi todos los términos de la ecuación de calor (1) calculada con el modelo NARR/NCEP mostraron una señal anual marcada (Fig. 3, Tabla 2), excepto el CL (Fig. 3c). El flujo de OL (Fig. 3a), que representa la radiación emitida por la superficie del océano menos la OL emitida por la atmósfera en la dirección del océano, tuvo una ganancia neta promedio de $460.84 \pm 25.16 \mathrm{~W} \mathrm{~m}^{-2}$, y el flujo de la luz del sol en el mar (OC) tuvo un valor promedio de $248.02 \pm$ $56.29 \mathrm{~W} \mathrm{~m}^{-2}$ (Fig. 3b). Como era de esperar, el CL (el flujo de calor hacia la atmósfera transportado por el agua evaporada) y el CS (el flujo de calor fuera del mar debido a la conducción de calor) presentaron valores negativos promedio de $71.91 \pm 37.20$ y $81.90 \pm 48.99 \mathrm{~W} \mathrm{~m}^{-2}$, respectivamente (Fig. 3c, d). La laguna de Tamiahua tuvo una ganancia neta de calor de $555.05 \pm 42.31 \mathrm{~W} \mathrm{~m}^{-2}$ durante todo el año (Fig. 3e). La correlación de cada término de la ecuación de 
Table 2. Cross-correlation between sea surface temperature and heat flux time series from 2003 to 2011 at Tamiahua Lagoon: SW, shortwave radiation; LW, longwave radiation; LH, latent heat flux; $\mathrm{SH}$, sensible heat flux. The significance levels of the computations were $P<0.00001$. Tabla 2. Correlación cruzada entre las series de tiempo de la temperatura superficial del mar y el flujo de calor de 2003 a 2011 en la laguna de Tamiahua; SW, radiación de onda corta; LW, radiación de onda larga; LH, flujo de calor latente; SH, flujo de calor sensible. Los niveles de significancia de los cálculos fueron de $P<0.00001$.

\begin{tabular}{lrrrrrrrrrr}
\hline Heat flux & 2003 & 2004 & 2005 & 2006 & 2007 & 2008 & 2009 & 2010 & 2011 \\
\hline SW & 0.42 & 0.54 & 0.41 & 0.52 & 0.49 & 0.43 & 0.38 & 0.48 & 0.54 \\
LW & 0.70 & 0.91 & 0.60 & 0.90 & 0.60 & 0.72 & 0.71 & 0.90 & 0.73 \\
LH & -0.60 & -0.79 & -0.82 & -0.60 & -0.67 & -0.74 & -0.02 & -0.76 & -0.53 \\
SH & -0.07 & -0.15 & 0.18 & -0.45 & 0.01 & -0.04 & -0.34 & -0.31 & -0.24 \\
Total & 0.40 & 0.70 & 0.26 & 0.60 & 0.40 & 0.50 & 0.42 & 0.62 & 0.51 \\
\hline
\end{tabular}

\section{Heat fluxes from the NARR/NCEP model}

In general, most of the terms of the bulk heat equation (1) computed with the NARR/NCEP model showed a marked annual signal (Fig. 3, Table 2) except LH (Fig. 3c). The LW flux (Fig. 3a), which represents the radiation emitted by the ocean surface minus the LW emitted by the atmosphere in the direction of the ocean, had a mean net gain value of $460.84 \pm 25.16 \mathrm{~W} \mathrm{~m}^{-2}$, and the flux of sunlight into the sea (SW) had a mean value of $248.02 \pm 56.29 \mathrm{~W} \mathrm{~m}^{-2}$ (Fig. 3b). As expected, the LH (the flux of heat carried by evaporated water) and $\mathrm{SH}$ (the flux of heat out of the sea due to heat conduction) had mean negative values of $71.91 \pm 37.20$ and $81.90 \pm 48.99 \mathrm{~W} \mathrm{~m}^{-2}$, respectively (Fig. 3c, d). Tamiahua Lagoon had a net heat gain of $555.05 \pm 42.31 \mathrm{~W} \mathrm{~m}^{-2}$ throughout the year (Fig. 3e). The correlation of each term of the bulk heat equation with the SST time series showed a maximum value for the LW term (0.60-0.91), followed by the SW term (0.38-0.54) (Table 2). The other two fluxes ( $\mathrm{LH}$ and $\mathrm{SH})$ generally showed negative correlations (Table 2). The low correlations computed for the $\mathrm{LH}$ and $\mathrm{SH}$ fluxes affected the computations of the correlation values $(0.26-0.70)$ estimated between the total heat fluxes and SST curve (Table 2).

\section{Mean and standard deviation fields of SST}

The spatial distributions of the SST field averaged over the study period and their standard deviation are shown in Figure 4(a, b). Mean SST increased from the Boca Corazones Inlet $\left(26^{\circ} \mathrm{C}\right)$ to the mid-western corridor of Ídolo Island $\left(28^{\circ} \mathrm{C}\right)$. From there to the central part of the lagoon, mean SST decreased by approximately $1{ }^{\circ} \mathrm{C}$, whereas at the western boundaries the temperature was higher than $27^{\circ} \mathrm{C}$, likely due to river discharge. A patch of water with a temperature of $28^{\circ} \mathrm{C}$ near Juan A. Ramírez Island decreased the temperature of the water extending along the eastern portion of Tamiahua Lagoon to Tampachichi Inlet to $26^{\circ} \mathrm{C}$. The mean SST field temperature computed over the study period was $26.59 \pm$ $3.29^{\circ} \mathrm{C}$. Because of its standard deviation and unlike the calor con la serie de tiempo de TSM presentó un valor máximo para el término OL (0.60-0.91), seguido por el término OC (0.38-0.54) (Tabla 2). Los otros dos flujos (CL y CS) generalmente mostraron correlaciones negativas (Tabla 2). Las bajas correlaciones calculadas para L y CS afectaron los cálculos de los valores de correlación (0.26-0.70) estimados entre los flujos totales de calor y la curva de TSM (Tabla 2).

\section{Campos promedio y de desviación estándar de la TSM}

Las distribuciones espaciales del campo de TSM promediadas para el periodo de estudio y su desviación estándar se muestran en la Figura 4(a,b). La TSM promedio aumentó de la entrada de Boca Corazones $\left(26^{\circ} \mathrm{C}\right)$ hacia el corredor medio-occidental de la isla Ídolo $\left(28^{\circ} \mathrm{C}\right)$. A partir de ahí y hasta la parte central de la laguna, el promedio de la TSM disminuyó aproximadamente $1{ }^{\circ} \mathrm{C}$, mientras que en los límites occidentales la temperatura fue mayor que $27^{\circ} \mathrm{C}$, probablemente debido a la descarga de los ríos. Cerca de la isla Juan A. Ramírez, se observó un parche de agua con una temperatura de $28{ }^{\circ} \mathrm{C}$ que disminuyó la temperatura del agua que se extiende a lo largo de la parte oriental de la laguna de Tamiahua y a la entrada de Tampachichi a $26^{\circ} \mathrm{C}$. La temperatura promedio del campo de TSM calculado a lo largo del periodo de estudio fue de $26.59 \pm 3.29{ }^{\circ} \mathrm{C}$. Debido a su desviación estándar, y a diferencia del campo promedio de TSM, se observó una variabilidad en frente de las bocas de los ríos que se encuentran al oeste de la laguna. La variabilidad se produjo en las partes sur y norte de la laguna. Por el contrario, el centro de la laguna retuvo una desviación estándar homogénea.

\section{Campos promedio y de desviación estándar de la Chla}

El campo promedio de la concentración de Chla fue $>11 \mathrm{mg} \mathrm{m}^{-3}$, principalmente en la región sur, donde se encuentra la entrada de Boca Corazones, y en el corredor occidental de la isla Ídolo (Fig. 5a). Se observó un parche de Chla con concentraciones $>16 \mathrm{mg} \mathrm{m}^{-3}$ frente al sistema estuarino Milpas. Concentraciones altas de Chla $\left(>16 \mathrm{mg} \mathrm{m}^{-3}\right)$ 

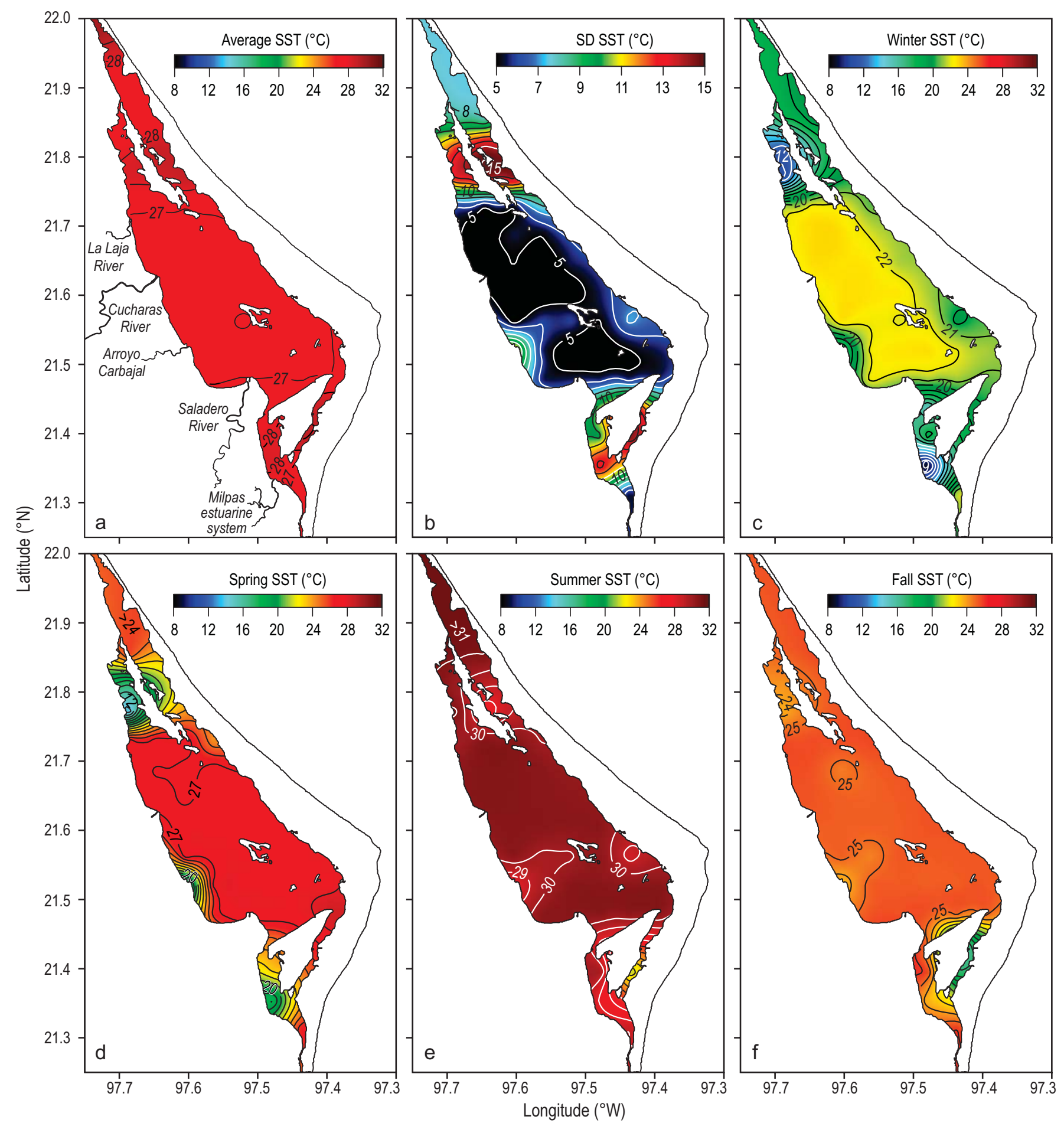

Figure 4. (a) Averaged sea surface temperature (SST) field for Tamiahua Lagoon. (b) Standard deviation (SD) of the SST field. (c) Winter SST. (d) Spring SST. (e) Summer SST. (f) Fall SST. All fields were computed from July 2002 to May 2012.

Figura 4. (a) Campo promedio de la temperatura superficial del mar (SST) de la laguna de Tamiahua. (b) La desviación estándar (SD) del campo de SST. (c) SST en invierno. (d) SST en primavera. (e) SST en verano. (f) SST en otoño. Todos los campos se calcularon de julio de 2002 a mayo de 2012. 
mean SST field, there was remarkably high variability in front of the river mouths located to the west of the lagoon. The variability occurred in the southern and northern portions of the lagoon. In contrast, the center of the lagoon retained a homogenous standard deviation.

\section{Mean and standard deviation fields of Chla}

The mean field of the Chla concentration was $>11 \mathrm{mg} \mathrm{m}^{-3}$, primarily in the southern region where Boca Corazones Inlet is located and in the western corridor of Ídolo Island (Fig. 5a). In front of the Milpas estuarine system, there was a patch of Chla with concentrations $>16 \mathrm{mg} \mathrm{m}^{-3}$. Higher values $\left(>16 \mathrm{mg} \mathrm{m}^{-3}\right)$ were found in the western area of the lagoon, in agreement with the river discharge locations (Fig. 1). The eutrophic water with high concentrations of Chla located in the southern area of the lagoon was spread around the eastern side of the lagoon due to local circulation. Moreover, the maximum values of the mean field were found in the corridor along Cabo Rojo and Juan A. Ramírez Island (eastern side of the lagoon). The values increased from $16 \mathrm{mg} \mathrm{m}^{-3}$ in the southwestern region of the Cabo Rojo sand barrier to more than $20 \mathrm{mg} \mathrm{m}^{-3}$ at Tampachichi Inlet. From both sides of Tamiahua Lagoon toward the center, the concentration of Chla decreased, with minimum concentrations reaching $<11 \mathrm{mg} \mathrm{m}^{-3}$. In general, the variability of Chla was homogenous in the center of the lagoon, with values $<2 \mathrm{mg} \mathrm{m}^{-3}$. The variability of the Chla field showed high values (which increased from 6 to $10 \mathrm{mg} \mathrm{m}^{-3}$ ) from Tampachichi Inlet toward the southeastern corridor (Juan A. Ramírez Island) and toward the western corridor formed by the island. The southern portion of the lagoon, the corridor formed by the western boundary of the area, and Ídolo Island showed high variability $\left(>11 \mathrm{mg} \mathrm{m}^{-3}\right)$, which was similar to that observed in the northern part of the lagoon (Fig. 5b).

\section{Temporal climatology of SST by season}

The SST seasonal time series built from the monthly images showed a strong annual pattern with a Gaussian shape during the year. The maximum temperature was found during summer $\left(30 \pm 0.15^{\circ} \mathrm{C}\right)$ and the minimum $\left(23 \pm 0.46^{\circ} \mathrm{C}\right)$ in winter. A slightly higher value of SST was determined during fall $\left(26 \pm 0.44^{\circ} \mathrm{C}\right)$ than that observed in winter. During spring, we observed an SST value of $2{ }^{\circ} \mathrm{C}\left(28 \pm 0.41^{\circ} \mathrm{C}\right)$ that was lower than that observed in summer.

\section{Spatial climatology of SST by season}

In winter (Fig. 4c), SST was less than $20^{\circ} \mathrm{C}$ in the southsouthwestern corridor of Ídolo Island and around Juan A. Ramírez Island; this water entered the lagoon through the Boca Corazones and Tampachichi inlets because of the exchange of water caused by the diurnal tides. Parts of the coastline in the western area, where the Laja and Saladero fueron observadas en la zona occidental de la laguna, de acuerdo con las ubicaciones de las descargas de los ríos (Fig. 1). El agua eutrófica con altas concentraciones de Chla se ubicó en la zona sur de la laguna y se extendió a todo el lado oriental de la laguna debido a la circulación local. Por otra parte, los valores máximos del campo promedio se observaron en el corredor a lo largo de cabo Rojo y la isla Juan A. Ramírez (lado oriental de la laguna). Estos valores aumentaron de $16 \mathrm{mg} \mathrm{m}^{-3}$ en la región suroeste de la barrera de arena de cabo Rojo a más de $20 \mathrm{mg} \mathrm{m}^{-3}$ en la entrada de Tampachichi. En ambos lados de la laguna de Tamiahua hacia el centro, la concentración de Chla disminuyó, con concentraciones mínimas de $<11 \mathrm{mg} \mathrm{m}^{-3}$. En general, la variabilidad de la Chla fue homogénea en el centro de la laguna, con valores $<2 \mathrm{mg} \mathrm{m}^{-3}$. La variabilidad del campo de Chla mostró valores máximos (que incrementaron de 6 a $10 \mathrm{mg} \mathrm{m}^{-3}$ ) desde la entrada de Tampachichi hacia el pasillo sudoriental (isla Juan A. Ramírez) y hacia el corredor occidental formado por la isla. En la parte sur de la laguna, en el corredor formado por el límite occidental de la zona, y la isla Ídolo se observó una alta variabilidad (>11 $\left.\mathrm{mg} \mathrm{m}^{-3}\right)$, que fue similar a la observada en la parte norte de la laguna (Fig. 5b).

\section{Climatología temporal de la TSM por estaciones del año}

La serie de tiempo de la TSM construida a partir de las imágenes mensuales mostró una marcada señal anual con una forma gaussiana a lo largo del año. La temperatura máxima se presentó durante el verano $\left(30 \pm 0.15^{\circ} \mathrm{C}\right)$, y la temperatura mínima $\left(23 \pm 0.46{ }^{\circ} \mathrm{C}\right)$ en el invierno. Se determinó un valor ligeramente más alto de TSM durante el otoño $\left(26 \pm 0.44{ }^{\circ} \mathrm{C}\right)$ que el observado en el invierno. En la primavera se observó un valor de TSM de $2{ }^{\circ} \mathrm{C}\left(28 \pm 0.41^{\circ} \mathrm{C}\right)$ que fue menor que el observado en el verano.

\section{Climatología espacial de la TSM por estaciones del año}

En invierno (Fig. 4c) la TSM presentó valores menores que $20^{\circ} \mathrm{C}$ en el corredor sur-suroeste de la isla Ídolo y alrededor de la isla Juan A. Ramírez; esta agua entró a la laguna por las entradas de Boca Corazones y Tampachichi debido al intercambio de agua causada por las mareas diurnas. Partes de la línea de costa de la región occidental, donde se encuentran los ríos La Laja y Saladero, mostraron aguas más frías, similares a las que penetraron a través de Boca Corazones y que se extendieron a la región noroeste de la laguna de Tamiahua. Fuera de esta zona, en la parte central de la laguna, la TSM incrementó de $20^{\circ} \mathrm{C}$ a $22^{\circ} \mathrm{C}$. En el norte, rodeando la parte oriental de la isla Juan A. Ramírez y la entrada de Tampachichi, la temperatura del agua fue más calida que el agua en la entrada de Boca Corazones.

Durante la primavera (Fig. 4d), la distribución espacial de la TSM fue similar a la del invierno. En la primavera y el invierno, se identificaron tres tipos de agua en tres regiones situadas a lo largo de la laguna. El primer tipo de agua, cuya 

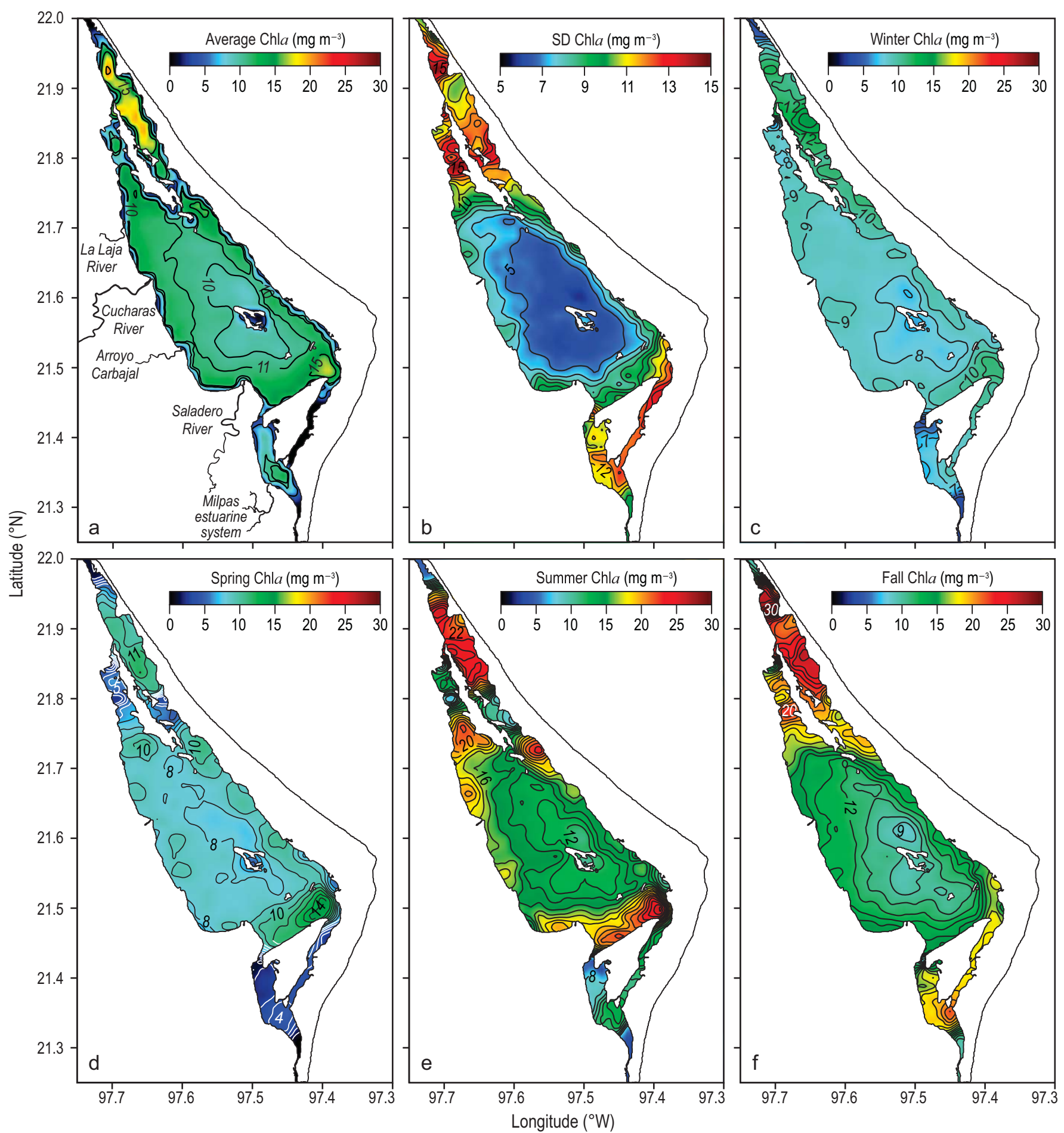

Figure 5. (a) Mean field of chlorophyll a (Chla) for Tamiahua Lagoon. (b) Standard deviation (SD) of the Chla field. (c) Winter Chla. (d) Spring Chla. (e) Summer Chla. (f) Fall Chla. All fields were computed from July 2002 to May 2012.

Figura 5. (a) Campo promedio de clorofila a (Chla) para la laguna de Tamiahua. (b) La desviación estándar (SD) del campo de Chla. (c) Chla en invierno. (d) Chla en primavera. (e) Chla en verano. (f) Chla en otoño. Todos los campos se calcularon de julio de 2002 a mayo de 2012. 
rivers are located, had cooler waters, similar to those that penetrated through Boca Corazones and spread to the northwestern area of Tamiahua Lagoon. Outside this area, in the central part of the lagoon, water temperature increased from 20 to $22{ }^{\circ} \mathrm{C}$. In the north, surrounding the eastern portion of Juan A. Ramírez Island and Tampachichi Inlet, the water temperature was warmer than the water in Boca Corazones Inlet.

During spring (Fig. 4d), the spatial distribution of SST was almost similar to that in winter. In spring and winter, three water types were identified in three areas of the lagoon. The first, with SST ranging from 15 to $20^{\circ} \mathrm{C}$, was observed from Boca Corazones to the southwestern corridor of Ídolo Island; this area showed a significant increase in water temperature in spring $\left(\sim 5^{\circ} \mathrm{C}\right)$ relative to the winter values. The second, with SST above $25^{\circ} \mathrm{C}$, was observed from the southern boundary of Ídolo Island to the northern part of Juan A. Ramírez Island, in the central portion of the lagoon. The third water type spread from the western part of the lagoon; it had a patch of water near the mouth of the Laja and Saladero rivers, with temperatures of 20 to $25^{\circ} \mathrm{C}$, similar to those observed in winter. To the north, near Juan A. Ramírez Island and Tampachichi Inlet, the water temperature was $25^{\circ} \mathrm{C}$, decreasing to $15^{\circ} \mathrm{C}$ in the southern portion of Juan $\mathrm{A}$. Ramirez Island; this water was warmer than that observed during winter.

In summer (Fig. 4e), the SST values in the lagoon increased by $10^{\circ} \mathrm{C}$ relative to the winter values and by $3{ }^{\circ} \mathrm{C}$ relative to the spring values (Fig. $4 \mathrm{c}, \mathrm{d}$ ). In addition, in the western part of the lagoon, the water discharged by Arroyo Carbajal (SST of approximately 29 to $30^{\circ} \mathrm{C}$ ) extended to the central portion of the lagoon and almost to the western flank of Toro Island (Fig. 1). The water discharged by the Saladero River and the Milpas estuarine system affected the distribution of SST along the western corridor between Boca Corazones and the northern portion of Ídolo Island, where the SST fluctuated from 28 to $29^{\circ} \mathrm{C}$ (Fig. 4e).

In fall (Fig. 4f), the spatial distribution of SST was similar to that of summer. In the region close to Boca Corazones and the southern area of Ídolo Island, SST was below $25^{\circ} \mathrm{C}$. Consequently, along the corridor structured by the western boundary of the lagoon, SST was $25^{\circ} \mathrm{C}$; this water spread to the central portion and southern part of Juan A. Ramírez Island. In front of the Arroyo Carbajal discharge, there was a patch of water with a temperature of $25^{\circ} \mathrm{C}$; this water penetrated into the central part of the lagoon near the western flank of Toro Island. At the Cabo Rojo sand barrier, it had a homogeneous temperature below $28^{\circ} \mathrm{C}$. To the north, where the western corridor is structured by Juan A. Ramírez Island and the land, SST varied from 23 to $25^{\circ} \mathrm{C}$. In the eastern corridor located in front of Tampachichi Inlet, SST was approximately $28^{\circ} \mathrm{C}$ and surrounded a patch of water with a temperature of approximately $24^{\circ} \mathrm{C}$. temperatura osciló entre 15 y $20{ }^{\circ} \mathrm{C}$, se observó desde Boca Corazones hasta el corredor sudoeste de la isla Ídolo; el agua en esta región mostró un aumento significativo de la temperatura $\left(\sim 5^{\circ} \mathrm{C}\right)$ en primavera en comparación con los valores de invierno. El segundo tipo de agua se observó desde el límite sur de la isla Ídolo hasta la parte norte de la isla Juan A. Ramírez, en la parte central de la laguna; en esta región se observó agua cálida con temperaturas superiores a $25^{\circ} \mathrm{C}$. El tercer tipo de agua se extendió desde la parte oeste de la laguna y mostró un parche de agua cerca de la desembocadura de los ríos Laja y Saladero, con temperaturas de 20 a $25^{\circ} \mathrm{C}$, similares a las observadas en invierno. Al norte, cerca de la isla Juan A. Ramírez y la entrada de Tampachichi, la temperatura del agua fue de $25^{\circ} \mathrm{C}$, la cual disminuyó a $15^{\circ} \mathrm{C}$ en la parte sur de la isla Juan A. Ramírez; esta agua fue más cálida que la observada durante el invierno.

En verano (Fig. 4e), los valores de la TSM en la laguna se incrementaron en $10^{\circ} \mathrm{C}$ con respecto a los valores de invierno y en $3{ }^{\circ} \mathrm{C}$ con respecto a los valores de primavera (Fig. $4 \mathrm{c}$, d). Además, en la parte occidental de la laguna donde se encuentra el arroyo Carbajal, la descarga de agua (TSM de aproximadamente 29 a $30^{\circ} \mathrm{C}$ ) penetró hasta la parte central de la laguna y casi hasta el flanco occidental de isla Toro (Fig. 1). El agua descargada por el río Saladero y el sistema estuarino Milpas afectó la distribución de la TSM a lo largo del corredor occidental situado entre Boca Corazones y la parte norte de la isla Ídolo, donde la TSM fluctuó de 28 a $29^{\circ} \mathrm{C}$ (Fig. 4e).

En otoño (Fig. 4f), se observó una distribución espacial de TSM similar a la de verano. En la región cerca de Boca Corazones y la zona sur de la isla Ídolo, los valores de TSM estuvieron por debajo de $25^{\circ} \mathrm{C}$. En consecuencia, a lo largo del corredor estructurado por el límite occidental de la laguna, la TSM fue de $25^{\circ} \mathrm{C}$; esta agua se extendió a la parte central y la parte sur de la isla Juan A. Ramírez. Frente a la descarga de Arroyo Carbajal, se observó un parche de agua con una temperatura de $25^{\circ} \mathrm{C}$; esta agua penetró a la parte central de la laguna cerca del flanco occidental de la isla Toro. En la barrera de arena Cabo Rojo, la temperatura presentó valores homogéneos y por debajo de $28^{\circ} \mathrm{C}$. Al norte, en la región donde el corredor occidental está estructurado por la isla Juan A. Ramírez y la porción de tierra, los valores de TSM variaron de 23 a $25^{\circ} \mathrm{C}$. En el corredor oriental situado en frente de la entrada de Tampachichi, el agua presentó una de TSM de aproximadamente $28^{\circ} \mathrm{C}$ y rodeó un parche de agua con una TSM de aproximadamente $24^{\circ} \mathrm{C}$.

\section{Climatología temporal de las concentraciones de Chla por estaciones del año}

Las series temporales de las concentraciones de Chla para el intervalo de tiempo analizado mostraron un valor promedio de $18.58 \pm 2.59 \mathrm{mg} \mathrm{m}^{-3}$ durante el verano. Durante las temporadas de invierno y primavera, las concentraciones promedio de Chla fueron semejantes a lo largo de toda la laguna: $9.48 \pm 1.03$ y $9.58 \pm 1.34 \mathrm{mg} \mathrm{m}^{-3}$, respectivamente. 


\section{Temporal climatology of Chla levels by season}

The monthly time series of Chla levels for the time interval analyzed showed a mean value of $18.58 \pm 2.59 \mathrm{mg} \mathrm{m}^{-3}$ during summer. During winter and spring, the mean Chla values were similar throughout the entire lagoon: $9.48 \pm 1.03$ and $9.58 \pm 1.34 \mathrm{mg} \mathrm{m}^{-3}$, respectively. In the fall, the mean concentration was $17.10 \pm 2.02 \mathrm{mg} \mathrm{m}^{-3}$, which was higher than that observed in winter and spring. In general, the temporal fluctuations of the Chla climatology showed the same annual signal observed for SST.

\section{Spatial climatology of Chla levels by season}

During winter, the spatial distribution of Chla levels (Fig. 5c) between Boca Corazones and the southwestern area of Ídolo Island varied from 6 to $10 \mathrm{mg} \mathrm{m}^{-3}$. In the northern area of Ídolo Island, the Chla values fluctuated from 9 to $11 \mathrm{mg} \mathrm{m}^{-3}$. Around Toro Island, there was a patch of water with a Chla concentration of $8 \mathrm{mg} \mathrm{m}^{-3}$. In the northern part of both corridors structured by Juan A. Ramírez Island, the Chla concentration tended to increase from 9 to $12 \mathrm{mg} \mathrm{m}^{-3}$ at Tampachichi Inlet. The average value for the spatial field of Chla during winter was $9.47 \pm 1.03 \mathrm{mg} \mathrm{m}^{-3}$.

During spring (Fig. 5d), the average concentration of the Chla spatial field was $9.58 \pm 1.33 \mathrm{mg} \mathrm{m}^{-3}$. This value was approximately equal to that computed for winter. From Boca Corazones to Ídolo Island the average Chla concentrations were less than $5 \mathrm{mg} \mathrm{m}^{-3}$. At the northern end of Ídolo Island and in the area of the Saladero River, the concentrations of Chla fluctuated from 10 to $14 \mathrm{mg} \mathrm{m}^{-3}$. At Toro Island and in the central part of the lagoon, there was a patch of water with lower concentrations $\left(<8 \mathrm{mg} \mathrm{m}^{-3}\right)$, similar to that observed in the winter field. In contrast, along the western boundary of the lagoon where the rivers discharge, higher levels were observed $\left(>9 \mathrm{mg} \mathrm{m}^{-3}\right)$. At Tampachichi Inlet, the concentrations of Chla varied from 10 to $11 \mathrm{mg} \mathrm{m}^{-3}$.

During summer (Fig. 5e), there was an increase in the concentrations of Chla relative to those computed for winter and spring. The mean Chla concentration was $18.58 \pm$ $2.59 \mathrm{mg} \mathrm{m}^{-3}$. Thus, summer had the maximum Chla values of all the seasons. Along the western boundary of the lagoon, a higher concentration was observed ( 8 to $20 \mathrm{mg} \mathrm{m}^{-3}$ ) due to water flowing from the Boca Corazones Inlet to the northwestern side of the lagoon and the northeastern portion of Ídolo Island. This water surrounded waters from the center of the lagoon, where concentrations were approximately 12 to $14 \mathrm{mg} \mathrm{m}^{-3}$, decreasing $\left(<12 \mathrm{mg} \mathrm{m}^{-3}\right)$ around Toro Island. In the area around Tampachichi Inlet and the eastern end of Juan A. Ramírez Island, the Chla concentrations are $>25 \mathrm{mg} \mathrm{m}^{-3}$.

During the fall (Fig. 5f), the Chla values ranged from 13 to $16 \mathrm{mg} \mathrm{m}^{-3}$ near the mouth of the Milpas estuary. On the western boundary of the lagoon, north of Saladero River and north of Ídolo Island, there were patches of water with a Chla concentration of $13 \mathrm{mg} \mathrm{m}^{-3}$. Surrounding Toro Island, there
La concentración promedio de Chla en otoño fue de $17.10 \pm 2.02 \mathrm{mg} \mathrm{m}^{-3}$, mayor que la observada en invierno y primavera. En general, las fluctuaciones temporales climatológicas de la Chla mostraron la misma señal anual observada para la TSM.

\section{Climatología espacial de las concentraciones de Chla por estaciones del año}

Durante el invierno, la distribución espacial de las concentraciones de Chla (Fig. 5c) entre Boca Corazones y la zona sudoriental de la isla Ídolo varió entre 6 y $10 \mathrm{mg} \mathrm{m}^{-3}$. En la zona norte de la isla Ídolo, los valores de Chla fluctuaron de 9 a $11 \mathrm{mg} \mathrm{m}^{-3}$. Alrededor de la isla Toro, hubo un parche de agua con una concentración de Chla de $8 \mathrm{mg} \mathrm{m}^{-3}$. En la parte norte de los dos corredores estructurados por la isla Juan A. Ramírez, la concentración de Chla tendió a aumentar de 9 a $12 \mathrm{mg} \mathrm{m}^{-3}$ en la entrada de Tampachichi. El valor promedio para el campo espacial de Chla durante el invierno fue $9.47 \pm 1.03 \mathrm{mg} \mathrm{m}^{-3}$.

Durante la primavera (Fig. 5d), la concentración promedio del campo espacial de la Chla fue $9.58 \pm 1.33 \mathrm{mg} \mathrm{m}^{-3}$. Este valor fue aproximadamente igual al calculado para el invierno. De Boca Corazones a la isla Ídolo la concentración promedio de Chla fue menor que $5 \mathrm{mg} \mathrm{m}^{-3}$. En el extremo norte de la isla Ídolo y en la zona del río Saladero, las concentraciones de Chla fluctuaron de 10 a $14 \mathrm{mg} \mathrm{m}^{-3}$. En isla Toro y en la parte central de la laguna, se observó un parche de agua con concentraciones más bajas $\left(<8 \mathrm{mg} \mathrm{m}^{-3}\right)$, similar a lo observado en el campo de invierno. Por el contrario, a lo largo del límite occidental de la laguna donde descargan los ríos, se observaron niveles más altos de Chla $\left(>9 \mathrm{mg} \mathrm{m}^{-3}\right)$. En la entrada de Tampachichi, las concentraciones de Chla variaron de 10 a $11 \mathrm{mg} \mathrm{m}^{-3}$.

Durante el verano (Fig. 5e), hubo un aumento en las concentraciones de Chla en relación con los valores calculados para invierno y primavera. La concentración promedio de Chla fue de $18.58 \pm 2.59 \mathrm{mg} \mathrm{m}^{-3}$. Por lo tanto, el verano presentó los valores máximos de Chla de todas las estaciones del año. A lo largo del límite occidental de la laguna, se observó una concentración de Chla más alta $\left(8 \mathrm{a} 20 \mathrm{mg} \mathrm{m}^{-3}\right.$ ) debido al agua que fluye de la entrada de Boca Corazones hacia el lado noroccidental de la laguna y la parte nororiental de la isla Ídolo. Esta agua rodeo aguas del centro de la laguna, donde las concentraciones de Chla fueron de aproximadamente 12 a $14 \mathrm{mg} \mathrm{m}^{-3}$, las cuales disminuyeron $\left(<12 \mathrm{mg} \mathrm{m}^{-3}\right)$ alrededor de la isla Toro. En el área que cubre la entrada de Tampachichi y el extremo oriental de la isla Juan A. Ramírez, las concentraciones de Chla fueron $>25 \mathrm{mg} \mathrm{m}^{-3}$.

Durante el otoño (Fig. 5f), los valores de Chla oscilaron entre 13 y $16 \mathrm{mg} \mathrm{m}^{-3}$ cerca de la desembocadura del sistema estuarino Milpas. En el límite occidental de la laguna, al norte del río Saladero y al norte de la isla Ídolo, se observaron parches de agua con una concentración de Chla de $13 \mathrm{mg} \mathrm{m}^{-3}$. Rodeando isla Toro, hubo un parche de agua con 
was a patch of water with a concentration of $10 \mathrm{mg} \mathrm{m}^{-3}$, which was surrounded by a water mass that showed a homogeneous concentration of $12 \mathrm{mg} \mathrm{m}^{-3}$. In the area west of Juan A. Ramírez Island and near the mouth of the Cucharas River, there was a patch of Chla with a concentration higher than $13 \mathrm{mg} \mathrm{m}^{-3}$. Between Tampachichi Inlet and the eastern corridor of Juan A. Ramírez Island, the Chla values were higher than $25 \mathrm{mg} \mathrm{m}^{-3}$, which were similar to the Chla concentrations found during summer. The average value for the spatial field of Chla for this season was $17.10 \pm 2.01 \mathrm{mg} \mathrm{m}^{-3}$.

\section{DisCuSSION}

Satellite images of SST and Chla collected from July 2002 to May 2012 in Tamiahua Lagoon, Mexico's third largest tropical coastal lagoon located in the western Gulf of Mexico, were used to explain their temporal and spatial fluctuations. The maximum value of the Chla curve during the summer of 2005 (Fig. 2b) could be related to episodes of heavy rainfall in the western Gulf of Mexico caused by atmospheric phenomena, including cold fronts, tropical storms and waves, and hurricanes in the study area (TejedaMartínez and Welsh-Rodríguez 2006). Like other coastal lagoons around the world, Tamiahua Lagoon is eutrophic $\left(\mathrm{Chla}>5 \mathrm{mg} \mathrm{m}^{-3}\right)$ because it receives nutrient loads from the rivers located in its western part (Nixon 1995); however, eutrophic conditions can also be caused by internal recycling processes between the sediment and water column circulation due to the shallowness of lagoons (Nixon 1995).

Contreras and Castañeda (2004) measured (in situ) average Chla concentrations around Tamiahua Lagoon ranging from 0.01 to $20.7 \mathrm{mg} \mathrm{m}^{-3}$, and they recorded the lowest Chla values $\left(<3 \mathrm{mg} \mathrm{m}^{-3}\right)$ in winter and the highest $\left(>15 \mathrm{mg} \mathrm{m}^{-3}\right)$ in summer. The average Chla value computed from the time series constructed with satellite images was $18.58 \pm 2.59 \mathrm{mg} \mathrm{m}^{-3}$, which is a lower Chla value than the average in-situ concentrations registered around Tamiahua Lagoon. Also, Contreras and Castañeda (2004) reported a maximum Chla value of $64.1 \mathrm{mg} \mathrm{m}^{-3}$ and in the present study the maximum value was $40 \mathrm{mg} \mathrm{m}^{-3}$. Thus, the Chla values derived from satellite images fall in the range of the in-situ observations reported by Contreras and Castañeda (2004). On the other hand, Ramírez-León et al. (2015) mentioned that the Chla values of shallow waters measured with satellite sensors tend to increase due to high concentrations of organic matter, detritus, or dissolved organic matter, but at least in the present study, the Chla values measured derived from satellite images and in-situ observations agree.

According to Trenberth's (1997) definition, warm (El Niño) and cold (La Niña) phases occur when SST anomalies are greater than $\pm 0.4{ }^{\circ} \mathrm{C}$ and have an interval of more than six months. The quantitative cross-correlation was computed between the SPA and ONI (Reynolds et al. 2008) during the periods that fit the ENSO definition, to establish a una concentración de Chla de $10 \mathrm{mg} \mathrm{m}^{-3}$, que estuvo rodeado por una masa de agua que mostró una concentración de Chla homogénea de $12 \mathrm{mg} \mathrm{m}^{-3}$. En la zona oeste de la isla Juan A. Ramírez y cerca de la desembocadura del río Cucharas, se observó un núcleo de Chla con una concentración superior a $13 \mathrm{mg} \mathrm{m}^{-3}$. Entre la entrada de Tampachichi y el corredor oriental de la isla Juan A. Ramírez, los valores de Chla fueron superiores a $25 \mathrm{mg} \mathrm{m}^{-3}$, que fueron similares a los valores de Chla encontradas durante el verano. El valor promedio para el campo espacial de la Chla para esta temporada fue $17.10 \pm 2.01 \mathrm{mg} \mathrm{m}^{-3}$.

\section{DISCUSIÓN}

Se recopilaron imágenes de satélite de la laguna de Tamiahua (oeste del golfo de México), la tercer laguna más grande de México, de julio de 2002 a mayo de 2012 y se utilizaron para analizar las fluctuaciones temporales y espaciales de la TSM y Chla. El valor máximo de la curva de Chla durante el verano de 2005 (Fig. 2b) podría estar asociado a episodios de fuertes lluvias en el oeste del golfo de México causadas por fenómenos atmosféricos, incluidos los frentes fríos, tormentas y ondas tropicales, y huracanes en todo el área de estudio (Tejeda-Martínez y Welsh-Rodríguez 2006). Al igual que otras lagunas costeras en el mundo, la laguna de Tamiahua es eutrófica $\left(\mathrm{Chl} a>5 \mathrm{mg} \mathrm{m}^{-3}\right)$ debido a que recibe descargas de nutrientes de los ríos situados en su parte occidental (Nixon 1995), pero las condiciones eutróficas también pueden producirse por procesos de reciclaje internos entre la sedimentación y la circulación de la columna de agua debido a la poca profundidad de la laguna (Nixon 1995).

Contreras y Castañeda (2004) realizaron mediciones in situ de Chla alrededor de la laguna de Tamiahua y registraron concentraciones promedio de entre 0.01 y $20.7 \mathrm{mg} \mathrm{m}^{-3}$; los valores más bajos los registraron en invierno $\left(<3 \mathrm{mg} \mathrm{m}^{-3}\right) \mathrm{y}$ los más altos $\left(>15 \mathrm{mg} \mathrm{m}^{-3}\right)$ en verano. El valor promedio de Chla calculado a partir de la construcción de series de tiempo con las imágenes de satélite resultó en $18.58 \pm 2.59 \mathrm{mg} \mathrm{m}^{-3}$, que es un valor de Chla inferior a la concentración promedio de las muestras recolectadas in situ alrededor de la laguna de Tamiahua. Además, en el estudio de Contreras y Castañeda (2004), se reporta un valor de Chla máximo de $64.1 \mathrm{mg} \mathrm{m}^{-3} \mathrm{y}$ en el presente estudio el valor máximo fue de $40 \mathrm{mg} \mathrm{m}^{-3}$. Por lo tanto, los valores de Chla derivados de imágenes de satélite están dentro del intervalo de las observaciones in situ reportados por Contreras y Castañeda (2004). Por otro lado, Ramírez-León et al. (2015) mencionaron que los valores de Chla de aguas poco profundas medidos con sensores de satélite tienden a ser elevados por las altas concentraciones de materia orgánica, detritus o materia orgánica disuelta; sin embargo, al menos en el presente estudio, los valores de Chla obtenidos con las imágenes de satélite y las observaciones in situ son similares.

De acuerdo con la definición de Trenberth (1997), las fases cálidas (El Niño) y frías (La Niña) se producen cuando 
quantitative remote correlation between the ENSO phases and the rainfall variability in the study area and thereby establish the interannual effects of rain (river runoff) on fluctuations in Chla concentration. For the warm phase (El Niño) (Fig. 2c), only one interval fit the ENSO definition and had a cross-correlation value of 0.60 (3 lag). For the ENSO cold phase (Fig. 2c), two periods fit Trenberth's (1997) definition and had cross-correlation values of $0.86(-1 \mathrm{lag})$ and 0.68 ( -1 lag). The analysis demonstrated the effect of the ENSO signal on the two phases, which affected the interannual variability of precipitation in the study area and thus of river runoff during the study period.

Concentrations of Chla and SST values can vary in coastal lagoons interannually. For example, in the Patos Lagoon estuary (southeast Brazil), where the concentration of Chla was studied over 25 years (1994-2008), the concentration ranged from 0.30 to $76.50 \mathrm{mg} \mathrm{m}^{-3}$ and the SST fluctuated from 8 to $30^{\circ} \mathrm{C}$ with a mean of $19.5^{\circ} \mathrm{C}$ (Fujita and Odebrecht 2007), which is $7{ }^{\circ} \mathrm{C}$ less than the mean temperature computed for Tamiahua Lagoon. The fluctuations of both parameters in Patos Lagoon were caused by precipitation in 1998 and 2002, when the area was strongly affected by El Niño. River runoff resulted in a high nutrient supply and a corresponding increase in Chla levels. In Tamiahua Lagoon, the quantitative correlation between seasonal precipitation and seasonal Chla concentration increased in the summer and fall seasons. In general, the cross-correlations were greater than 0.7 , primarily with a phase lag of 0 (Table 1). In the Patos Lagoon estuary, during strong El Niño years precipitation was extremely high $\left(1,500 \mathrm{~mm} \mathrm{month}{ }^{-1}\right)$ and river discharges introduced a large amount of sediment and increased turbidity; therefore, primary biomass decreased. According to the ONI (Reynolds et al. 2008), in Tamiahua Lagoon the SPA is negative during El Niño periods and generally positive during La Niña. Thus, according to the qualitative correlation between SPA fluctuation and the ONI (Fig. 2c), the summer precipitation peaks in 2007 and 2011 developed during the ENSO cold phase and caused an increase in rainfall in the study area (Torres-Alavez et al. 2010); however, it has been well documented by Torres-Alavez et al. (2010) that other atmospheric phenomena also caused an increase in rainfall in the study area, particularly in 2010. Hence, the La Niña signal had an effect on the increase in precipitation in Tamiahua Lagoon and, thus, on river runoff, which affected Chla concentrations. In other lagoons of the world, the La Niña phenomenon tends to decrease rainfall, river discharges, and nutrient inputs and increase evaporation, resulting in decreased SST and Chla levels (Abreu et al. 2010, CoutinhoHennemann and Mello-Pretucio 2011). Moreover, the crosscorrelation between SST and Chla values was generally higher in summer and fall than in winter and spring (Table 3). Thus, the warmer river waters transport waters with high Chla concentrations to the lagoon (Kerjvfe 1994).

The SST and Chla levels of the Tamiahua Lagoon waters showed strong variability near the Boca Corazones and las anomalías de la TSM son mayores que $\pm 0.4{ }^{\circ} \mathrm{C}$ y tienen un intervalo de más de seis meses. La correlación cruzada cuantitativa se calculó entre la APE y el ONI (Reynolds et al. 2008) durante los periodos que se ajustan a la definición de ENOS, para establecer una correlación cuantitativa entre las fases ENOS y la variabilidad de lluvia en el área de estudio y de esta manera establecer los efectos interanuales de la época de lluvias (escorrentía de los ríos) en las fluctuaciones de la concentración de Chla. Para la fase cálida (El Niño) (Fig. 2c), sólo un intervalo se ajusta a la definición ENOS y tuvo un valor de correlación cruzada de 0.60 (fase de retardo de 3 ). Para la fase fría del ENOS (Fig. 2c), dos periodos se ajustan a la definición de Trenberth (1997) y tuvieron valores de correlación cruzada de 0.86 (fase de retardo de -1) y 0.68 (fase de retardo de -1). El análisis demostró el efecto de la señal de ENOS en las dos fases, lo que afectó la variabilidad interanual de la precipitación en el área de estudio y, por lo tanto, el caudal de los ríos durante el periodo de estudio.

Las concentraciones de Chla y los valores de TSM pueden variar interanualmente en las lagunas costeras. Por ejemplo, en el estuario Laguna de los Patos (sudeste de Brasil), donde se estudió la concentración de Chla durante 25 años (1994-2008), la concentración osciló de 0.30 a $76.50 \mathrm{mg} \mathrm{m}^{-3}$ y los valores de la TSM fluctuaron entre $8 \mathrm{y}$ $30{ }^{\circ} \mathrm{C}$ con un valor promedio de $19.5^{\circ} \mathrm{C}$ (Fujita y Odebrecht 2007), el cual es $7^{\circ} \mathrm{C}$ menor que la temperatura calculada para la laguna de Tamiahua. Las fluctuaciones en ambos parámetros en el estuario Laguna de los Patos fueron causadas por la precipitación en los años 1998 y 2002, cuando El Niño tuvo sus mayores efectos en la zona. El caudal de los ríos introdujo concentraciones altas de nutrientes $\mathrm{y}$, por lo tanto, un aumento en los niveles de Chla. En la laguna de Tamiahua la correlación cuantitativa entre la precipitación estacional y la concentración de Chla estacional aumentó en las temporadas de verano y otoño. En general, las correlaciones cruzadas fueron mayores que 0.7 , principalmente con un retardo de fase de 0 (Tabla 1). En el estuario Laguna de los Patos, durante años Niño intensos las precipitaciones fueron extremadamente altas $\left(1,500 \mathrm{~mm} \mathrm{mes}^{-1}\right)$, y las descargas de los ríos arrojaron una gran cantidad de sedimento e incrementaron la turbidez; por lo tanto, la biomasa primaria disminuyó. En la laguna de Tamiahua, de acuerdo con el ONI (Reynolds et al. 2008), el APE fue negativo durante El Niño y generalmente positivo durante La Niña. Por lo tanto, de acuerdo con la correlación cualitativa entre las fluctuaciones de la APE y el ONI (Fig. 2c), los picos de precipitación de verano de 2007 y 2011 se desarrollaron en la fase fría del ENOS, lo que causó un aumento en las precipitaciones en la zona de estudio (Torres-Alavez et al. 2010); sin embargo, está bien documentado por Torres-Alavez et al. (2010) que otros fenómenos atmosféricos también causaron un aumento en las precipitaciones en la zona de estudio, sobre todo en 2010. Por lo tanto, la señal de La Niña tuvo un efecto sobre el aumento en las precipitaciones en la laguna de Tamiahua y, consecuentemente, el caudal de los ríos, lo que afectó las 
Table 3. Cross-correlation between sea surface temperature and chlorophyll $a$ time series at zero lag, from July 2002 to May 2012 at Tamiahua Lagoon. The significance levels of the computations were $P<0.0001$.

Tabla 3. Correlación cruzada entre las series de tiempo de clorofila $a$ y temperatura superficial del mar a un retardo de cero, de julio de 2002 a mayo de 2012 en la laguna de Tamiahua. Los niveles de significancia de los cálculos fueron de $P<0.0001$.

\begin{tabular}{lcccccccccccc}
\hline Season & 2002 & 2003 & 2004 & 2005 & 2006 & 2007 & 2008 & 2009 & 2010 & 2011 & 2012 \\
\hline Winter & - & 0.38 & 0.89 & 0.63 & 0.64 & 0.53 & 0.57 & 0.59 & 0.63 & 0.60 & 0.60 \\
Spring & - & 0.69 & 0.74 & 0.61 & 0.59 & 0.78 & 0.83 & 0.92 & 0.61 & 0.53 & 0.50 \\
Summer & 0.92 & 0.81 & 0.65 & 0.94 & 0.98 & 0.68 & 0.70 & 0.98 & 0.72 & 0.79 & - \\
Fall & 0.86 & 0.46 & 0.87 & 0.87 & 0.68 & 0.84 & 0.90 & 0.99 & 0.99 & 0.96 & - \\
\hline
\end{tabular}

Tampachichi inlets. This variability can be explained by the diurnal exchange of Gulf of Mexico waters with Tamiahua Lagoon (Salas-Pérez et al. 2008). Moreover, Tamiahua Lagoon has been described as a constant reservoir containing estuarine-type warm water that is temporarily affected by discharges of continental water and continental shelf water entering through the Boca Corazones and Tampachichi inlets. These water types that were introduced into the lagoon by diurnal tide forcing and river discharges in conjunction generated three water types previously mentioned in the results section. In the Venetian Lagoon (Italy), the temporal evolution of the spatial distribution revealed the role of river discharges and tide exchanges with the sea to determine water quality parameters and ecosystem dynamics (Solidoro et al. 2004). The LW heat flux showed the largest correlation values (between 0.60 and 0.91 ) among all terms of the net flux, implying that it was most important in the modulation of the SST fields of Tamiahua Lagoon. Although this was the poorest heat flux quantified from the reanalysis output models, over sea surface, the differences in LW were substantially smaller than those over land sites, likely because oceans are spatially homogeneous (Wang and Dickinson 2013). Nonetheless, these results explain the high temperatures (about $27^{\circ} \mathrm{C}$ ) observed throughout the year within Tamiahua Lagoon.

\section{ACKNOWLEDGMENTS}

This study was supported by funds from the Secretaría de Educación Pública (Ministry of Public Education, Mexico), within the framework of the project: Bases para el Análisis y Síntesis de los Sistemas Costeros de Veracruz.

\section{REFERENCES}

Abreu PC, Bergesch M, Proença LA, Garcia CA, Odebrecht C. 2010. Short- and long-term chlorophyll- $a$ variability in the shallow microtidal Patos Lagoon estuary, southern Brazil. Estuar. Coasts 33: 554-569.

Contreras F, Castañeda O. 2004. Las lagunas costeras y estuarios del golfo de México: Hacia el establecimiento de índices ecológicos. In: Caso M, Pisanty I, Ezcurra E (eds.), Diagnóstico Ambiental del Golfo de México. Instituto Nacional de Ecología, Secretaría de Medio Ambiente y Recursos Naturales pp. 373-416. concentraciones de Chla. En otras lagunas del mundo, el fenómeno de La Niña tiende a disminuir las precipitaciones, descargas de los ríos y los aportes de nutrientes y a aumentar la evaporación, lo cual resulta en una disminución de la TSM y las concentraciones de Chla (Abreu et al. 2010, CoutinhoHennemann y Mello-Pretucio 2011). Además, la correlación cruzada entre los valores de TSM y Chla generalmente fue más alta en verano y otoño que en invierno y primavera (Tabla 3). Esto significa que las aguas más cálidas de los ríos transportan altas concentraciones de Chla a la laguna (Kerjvfe 1994).

La TSM y las concentraciones de Chla de las aguas de la laguna de Tamiahua mostraron una fuerte variabilidad cerca de las entradas de Boca Corazones y Tampachichi. Esta variabilidad puede ser explicada por el intercambio diurno de las aguas del golfo de México con las aguas de la laguna de Tamiahua (Salas-Pérez et al. 2008). Por otra parte, la laguna de Tamiahua se ha descrito como un reservorio que contiene agua cálida tipo estuarina que se ve afectada temporalmente por los vertidos de aguas continentales y de aguas provenientes de la plataforma continental que entran a través de las entradas de Boca Corazones y Tampachichi. Estas aguas que se introducen a la laguna por el forzamiento de la marea diurna y las descargas de los ríos, en conjunto, generan los tres tipos de agua previamente mencionados en la sección de resultados. En la laguna de Venecia (Italia), la evolución temporal de la distribución espacial reveló el papel de las descargas de los ríos y los intercambios de marea con el mar para determinar los parámetros de calidad del agua y la dinámica del ecosistema (Solidoro et al. 2004). El flujo de calor OC mostró los mayores valores de correlación (entre 0.60 y 0.91 ) entre todos los términos del flujo neto de calor, lo cual implica que es el flujo de calor más importante en la modulación de los campos de TSM de la laguna de Tamiahua. Aunque éste sea el flujo de calor cuantificado con mayor incertidumbre a partir del modelo de reanálisis, sobre la superficie del mar, las diferencias en el flujo de calor OC fueron sustancialmente más pequeñas que las cuantificadas en zonas terrestres, probablemente porque los océanos son espacialmente homogéneos (Wang y Dickinson 2013). No obstante, estos resultados explican las altas temperaturas (alrededor de $27^{\circ} \mathrm{C}$ ) observadas durante todo el año dentro de la laguna de Tamiahua. 
Coutinho-Hennemann M, Mello-Petrucio M. 2011. Spatial and temporal dynamic of trophic relevant parameters in a subtropical coastal lagoon in Brazil. Environ. Monit. Assess. 181: 347-361.

Elliott M, Quintino V. 2007. The estuarine quality paradox, environmental homeostasis and the difficulty of detecting anthropogenic stress in naturally stressed areas. Mar. Pollut. Bull. 54: 640-645.

Fujita CC, Odebrecht C. 2007. Short-term variability of chlorophyll $a$ and phytoplankton composition in a shallow area of the Patos Lagoon estuary (southern Brazil). Atlântica, Rio Grande 29(2): 93-106.

Kjerfve B. 1994. Coastal lagoons. In: Kjerfve B (ed.), Coastal Lagoons Processes. Elsevier Oceanography Series 60. Elsevier Science Publishers, B.V., 8 pp.

Medina-Gómez I, Herrera-Silveira JA. 2006. Primary production dynamics in a pristine groundwater-influenced coastal lagoon of the Yucatan Peninsula. Cont. Shelf Res. 26: 976-981.

Mesinger F, Dimego G, Kalnay E, Mitchell K, Shafran PC, Ebizuzaki W, Jovic D, Wollen J, Rogers E, Berbery EH, Ek MB, Fan Y, Grumbine R, Higgins W, Li H, Lin Y, Manikin G, Parrish D, Shi W. 2006. North American regional reanalysis. Bull. Am. Meteorol. Soc. 87: 343-360.

Nixon SW. 1995. Coastal marine eutrophication: A definition, social causes, and future concerns. Ophelia 41: 199-219.

Ramírez-León MR, Álvarez-Borrego S, Turrent-Thompson C, Gaxiola-Castro G, Heckel-Dziendzielewski G. 2015. Nutrient input from the Colorado River to the northern Gulf of California is not required to maintain a productive pelagic ecosystem $=\mathrm{El}$ aporte de nutrientes del río Colorado al norte del golfo de California no se requiere para mantener un ecosistema pelágico productivo. Cienc. Mar. 41(2): 169-188. http://dx.doi.org/10.7773/cm.v41i2.2483

Reynolds RW, Peterson TC, Lawrimore J. 2008. Improvements to NOAA's historical merged land-ocean surface temperature analysis (1880-2006). J. Clim. 21: 2283-2296.

\section{Agradecimientos}

Este estudio fue financiado con fondos de la Secretaría de Educación Pública (México), dentro del marco del proyecto: Bases para el Análisis y Síntesis de los Sistemas Costeros de Veracruz.

Salas-Pérez JJ, Salas-Monreal D, Arenas-Fuentes V, Salas-de-León DA, Riveron-Enzástiga, ML. 2008. Tidal characteristics in a coral reef system from the western Gulf of Mexico = Características de la marea en un sistema arrecifal coralino del golfo de México occidental. Cienc. Mar. 34(4): 467-478.

Solidoro C, Pastres R, Cossarini G, Ciavatta S. 2004. Seasonal and spatial variability of water quality parameters in the lagoon of Venice. J. Mar. Syst. 51: 7-18.

Tejeda-Martínez A, Welsh-Rodríguez C. 2006. Inundaciones 2005 en el Estado de Veracruz. Universidad Veracruzana, México, $353 \mathrm{pp}$.

Torres-Alavez A, Tejeda-Martínez A, Vázquez-Aguirre JL, BrunetIndia M, Hernández-Avila P, Ruiz-Barradas A. 2010. Índices de cambio climático y análisis de variabilidad en el estado de Veracruz, México, In: Fernández-García F, Galán-Gallego E, Cañada Torrecilla R (eds.), Memorias del VII Congreso de la Asociación Española de Climatología: Clima, Ciudad y Ecosistemas. Serie A, no. 7. Madrid, pp. 295-304.

Trenberth KE. 1997. The definition of El Niño. Bull. Am. Meteorol. Soc. 78: 2771-2777.

Wang K, Dickinson RE. 2013. Global atmospheric downward longwave radiation at the surface from ground-based observations, satellite retrievals, and reanalyses. Rev. Geophys. 51: $150-185$.
Received June 2015, accepted February 2016. 